\title{
MOLECULAR PHYLOGENY OF THE CLADOPHORACEAE (CLADOPHORALES, ULVOPHYCEAE), WITH THE RESURRECTION OF ACROCLADUS NÄGELI AND WILLEELLA BØRGESEN, AND THE DESCRIPTION OF LUBRICA GEN. NOV. AND PSEUDORHIZOCLONIUM GEN. NOV. ${ }^{1}$
}

\author{
Christian Boedeker ${ }^{2}$ \\ School of Biological Sciences, Victoria University of Wellington, Kelburn Parade, Wellington 6140, New Zealand \\ Frederik Leliaert \\ Phycology Research Group, Biology Department, Ghent University, Krijgslaan 281 S8, 9000 Ghent, Belgium \\ and Giuseppe C. Zuccarello \\ School of Biological Sciences, Victoria University of Wellington, Kelburn Parade, Wellington 6140, New Zealand
}

The taxonomy of the Cladophoraceae, a large family of filamentous green algae, has been problematic for a long time due to morphological simplicity, parallel evolution, phenotypic plasticity, and unknown distribution ranges. Partial large subunit (LSU) rDNA sequences were generated for 362 isolates, and the analyses of a concatenated dataset consisting of unique LSU and small subunit (SSU) rDNA sequences of 95 specimens greatly clarified the phylogeny of the Cladophoraceae. The phylogenetic reconstructions showed that the three currently accepted genera Chaetomorpha, Cladophora, and Rhizoclonium are polyphyletic. The backbone of the phylogeny is robust and the relationships of the main lineages were inferred with high support, only the phylogenetic position of both Chaetomorpha melagonium and Cladophora rupestris could not be inferred unambiguously. There have been at least three independent switches between branched and unbranched morphologies within the Cladophoraceae. Freshwater environments have been colonized twice independently, namely by the freshwater Cladophora species as well as by several lineages of the Rhizoclonium riparium clade. In an effort to establish monophyletic genera, the genera Acrocladus and Willeella are resurrected and two new genera are described: Pseudorhizoclonium and Lubrica.

Key index words: Chaetomorpha; Cladophora; green algae; molecular phylogenetics; polyphyly; rDNA; Rhizoclonium; taxonomy

Abbreviations: BI, Bayesian Inference; bp, base pairs; ITS, internally transcribed spacer; LSU, large ribosomal subunit; ML, maximum likelihood; rDNA,

\footnotetext{
${ }^{1}$ Received 1 March 2016. Accepted 6 June 2016.

${ }^{2}$ Author for correspondence: e-mail christian.boedeker@vuw.ac.nz.

Editorial Responsibility: H. Verbruggen (Associate Editor)
}

ribosomal DNA; s. 1., sensu lato; s. s., sensu stricto; SSU, small ribosomal subunit

The Cladophorales (Ulvophyceae, Chlorophyta) is a large group of essentially filamentous green algae, and contains several hundred species that occur in almost all types of aquatic habitats across the globe. Species of Cladophorales have rather simple morphologies, ranging from branched or unbranched uniseriate filaments to modified body plans such as networks of anastomosing filaments or inflated giant cells (van den Hoek et al. 1995). In addition to the morphological simplicity of the Cladophorales and the resulting low number of morphological characters that are useful in diagnosing species, both phenotypic plasticity and convergent evolution of characters are common in this group (van den Hoek 1963, Leliaert and Boedeker 2007, Leliaert et al. 2009a,c, Boedeker et al. 2012). This combination resulted in extensive taxonomic confusion at all levels, from species and genera to families and orders.

The taxonomic position of the Cladophorales has been subject to debate. Although the order has been generally placed in the Ulvophyceae sensu Mattox and Stewart (1984), some authors have advocated to separate the Cladophorales in a class of their own, Cladophorophyceae nom. nud. (van den Hoek et al. 1995). However, there is mounting molecular evidence that the Ulvophyceae sensu Mattox and Stewart (1984) represents a natural group (López-Bautista and Chapman 2003, Watanabe and Nakayama 2007, Cocquyt et al. 2010) which includes the Cladophorales. Conversely, chloroplast multigene phylogenies generally fail to recover a monophyletic Ulvophyceae (Fučíková et al. 2014, Leliaert and Lopez-Bautista 2015). The recognition at the ordinal level has also been controversial and 
remains confusing. Repeated re-interpretation of pre-molecular characters has led to the recognition of either two or just one order, and resulted in the following scenarios: a single order Siphonocladales (Børgesen 1913, Feldmann 1938, Jónsson 1965, O'Kelly and Floyd 1984), a single order Cladophorales (Chapman and Chapman 1973, van den Hoek 1984, van den Hoek and Womersley 1984), or two separate orders Siphonocladales s.s. and Cladophorales s.s. (Børgesen 1948, Egerod 1952, Womersley 1984, Bold and Wynne 1985). Analysis of molecular data established the existence of two main sister clades, one essentially corresponding to the Siphonocladales s.s (best referred to at the moment as the Siphonocladus clade instead of Siphonocladaceae as it contains several families) and the other to the Cladophorales s.s. (Leliaert et al. 2003) which is equivalent to Cladophoraceae (sensu Wille 1890). Members of the marine Siphonocladus clade are distributed mainly in the tropics and include forms with more complex architecture in addition to Cladophora-like filamentous taxa (Leliaert et al. 2007). Thus, currently one order Cladophorales is recognized, that includes the family Cladophoraceae (which contains the type species of the genus Cladophora). This clade will be the focus of this study.

Molecular data led to the recognition of three additional small families within the Cladophorales. The monotypic Okellyaceae is sister to the rest of the Cladophorales and is represented by the unbranched marine filamentous species Okellya curvata Leliaert \& Rueness (Leliaert et al. 2009a). The marine Pseudocladophoraceae and the mainly brackish and freshwater Pithophoraceae both contain species with Cladophora-like morphologies (Hanyuda et al. 2002, Boedeker et al. 2012), which illustrates the taxonomic challenges in this group. How often branched Cladophora-like body plans and unbranched morphologies evolved independently in this order remains poorly understood and therefore several genera remain polyphyletic despite recent efforts to make progress in understanding their evolutionary history and adapting the taxonomy (Leliaert et al. 2009a,b,c, 2011a, Boedeker et al. 2012, Ichihara et al. 2013).

Members of the Cladophoraceae are distributed from the tropics to cold temperate and polar waters, and the three currently and widely accepted genera of the family are Chaetomorpha Kützing, Cladophora Kützing and Rhizoclonium Kützing (Fig. 1). Several other genera have been erected within the Cladophoraceae but most of those taxa have been synonymized with either Chaetomorpha, Cladophora, or Rhizoclonium, or have been transferred to different orders and even phyla (see Table S1 in the Supporting Information).

The branched genus Cladophora is one of the largest and taxonomically most challenging genera of green algae, with more than 1,000 taxa that have been described (Guiry and Guiry 2015). A ground breaking effort to sort out the taxonomy and nomenclature of Cladophora was done by van den Hoek (1963) who reduced a vast number $(>500)$ of Cladophora taxa to 34 species for Europe and reclassified them into 11 sections of the genus (12 sections in later treatments). Taxonomic revisions of the genus were later extended to other parts of the world (van den Hoek 1982, van den Hoek and Womersley 1984, van den Hoek and Chihara 2000). However, molecular sequence data have shown that so far none of the Cladophora sections represents a natural group (Bakker et al. 1994, Hanyuda et al. 2002, Leliaert et al. 2009a, Boedeker et al. 2012). Species-level taxonomy is impeded by considerable morphological plasticity, which is displayed in the majority of species. This morphological variability of Cladophora species depending on environmental conditions has been well-documented (e.g., van den Hoek 1963, Parodi and Cáceres 1993, Leliaert and Boedeker 2007). The main diagnostic features for species identification are cell dimensions, branching pattern, rhizoid formation, and overall thallus organization. More than 200 species are currently recognized worldwide (Guiry and Guiry 2015), but this number likely does not reflect the actual number of species. While phenotypic plasticity led to superfluous species descriptions and inflated estimates of species diversity, molecular methods have uncovered cryptic diversity in several Cladophora morphospecies (Bakker et al. 1995, van den Hoek and Chihara 2000, Ichihara et al. 2013), and many species likely remain to be discovered.

Chaetomorpha consists of attached or unattached unbranched filaments and is restricted to marine environments with few species penetrating into brackish areas. The taxonomy of Chaetomorpha is nearly as chaotic as of the genus Cladophora, especially with regards to tropical species. About 120 taxa have been described (Guiry and Guiry 2015), based on the few characters available in these unbranched filaments. Commonly used diagnostic characters within the genus are filament diameter, shape and size of the basal cells, length-width ratio of the cells, presence of constrictions between cells, and the distinction between unattached or attached growth (Leliaert and Boedeker 2007).

Rhizoclonium filaments are thinner than in Chaetomorpha and can form short lateral rhizoids. The genus is distributed worldwide, in freshwater as well as in brackish and intertidal marine environments (Nienhuis 1975). More than 70 taxa of Rhizoclonium have been described (Guiry and Guiry 2015), but diagnostic morphological characters are not welldefined and hence species are poorly circumscribed. Moreover, molecular data indicate rampant cryptic diversity (Leliaert and Boedeker 2007, Ichihara et al. 2013). Furthermore, molecular phylogenetic studies have demonstrated that Rhizoclonium is polyphyletic (Hanyuda et al. 2002). 


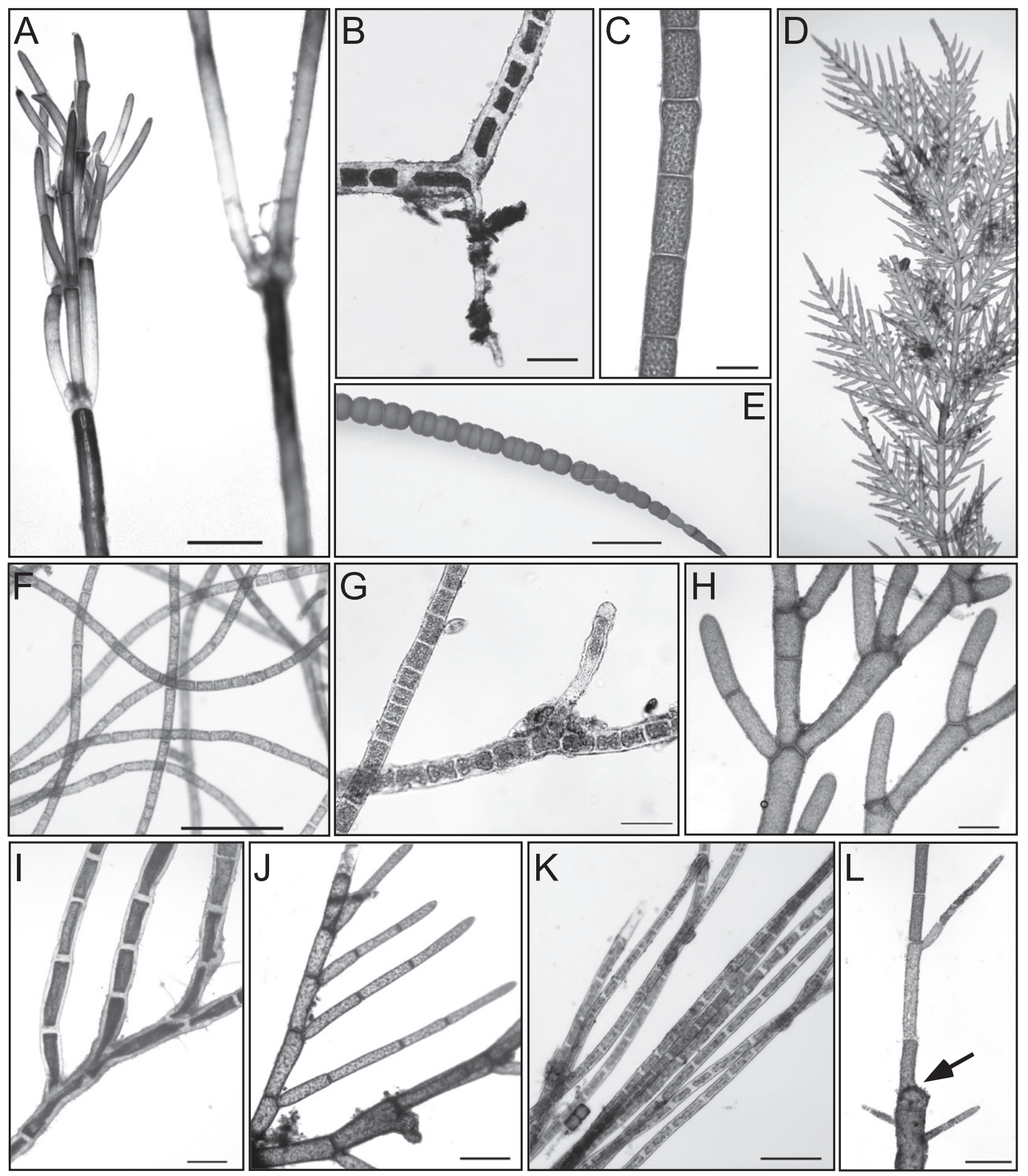

FIG. 1. Morphological diversity within the Cladophoraceae. (A) Cladophora pellucida (= Acrocladus pellucidus), apical part of thallus showing dense acropetal branching and long cells in main filaments, scale bar $=1 \mathrm{~mm}$. (B) Rhizoclonium africanum (=Pseudorhizoclonium africanum comb. nov.), unbranched filament with lateral rhizoid showing characteristic thick cell walls, field material, scale bar $=100 \mu \mathrm{m}$. $(\mathrm{C})$ Rhizoclonium africanum (=Pseudorhizoclonium africanum comb. nov.), culture of field material shown in (B), unbranched filament with thin cell walls, scale bar $=100 \mu \mathrm{m}$. (D) Cladophora ordinata (=Willeella ordinata), upper part of thallus showing characteristic opposite branching, scale bar $=500 \mu \mathrm{m}$. (E) Chaetomorpha coliformis, basal region of unbranched filament showing the characteristic giant cells organized in pairs, scale bar $=5 \mathrm{~mm}$. (F) Chaetomorpha ligustica, thin unbranched filaments, scale bar $=500 \mu \mathrm{m}$. (G) Rhizoclonium "riparium," unbranched filaments with lateral rhizoids, scale bar $=50 \mu \mathrm{m} .(\mathrm{H})$ Cladophora laetevirens, branched thallus, scale bar $=200 \mu \mathrm{m}$. (I) Cladophora glomerata, basal part of thallus with thick cell walls and irregular insertion of branches, scale bar $=200 \mu \mathrm{m}$. (J) Cladophora glomerata, densely branched apical part of thallus showing acropetal growth, scale bar $=200 \mu \mathrm{m}$. (K) Cladophora cf. fracta, unbranched filaments, scale bar $=100 \mu \mathrm{m}$. (L) Cladophora rivularis, variability in culture, with drastically reduced filament width in culture (arrow indicates transition) compared to thicker diameter as encountered in the field, scale bar $=50 \mu \mathrm{m}$. 
Several species of Cladophoraceae have large ecological ranges, which is partly responsible for the phenotypic variability. Species may occur in a wide range of conditions and habitats, or are found in habitats with fluctuating environmental conditions such as the intertidal or estuaries, indicating the ability for effective osmoacclimation. Both the marine species Cladophora vagabunda (L.) van den Hoek and the freshwater species C. glomerata (L.) Kützing can penetrate into brackish waters (van den Hoek 1963, Hayakawa et al. 2012). The Cladophoraceae is one of the few algal groups in which the boundary between marine and freshwater environments is frequently crossed (Round and Sims 1981, Logares et al. 2007). Cladophora is an important genus in ecological terms, being widespread and abundant and therefore contributing significantly to nutrient cycling and oxygen production. Both in marine and freshwater environments, Cladophora provides habitats for epiphytes and invertebrates and has been referred to as an ecosystem engineer (Zulkifly et al. 2013). Under favorable conditions, Cladophora is known to form conspicuous macroalgal blooms, or green tides, where nutrients accumulate and competition is reduced (Gubelit and Kovalchuk 2010, Zulkifly et al. 2013, Pochon et al. 2015). These blooms can reach nuisance levels and can have negative economic impacts (Dodds 1991, Zulkifly et al. 2013, Pochon et al. 2015). The freshwater species Cladophora glomerata is a locally important food for humans and in fish aquaculture in parts of Southeast Asia (Peerapornpisal et al. 2006).

The aim of this study is to infer the phylogenetic relationships in the Cladophoraceae based on the LSU and SSU rDNA sequences of 95 specimens, carefully selected from a dataset of 362 cladophoracean LSU sequences from all over the world. This is the first well-sampled phylogeny of the Cladophoraceae, which provides new insights into the relationships, morphological evolution (including repeated independent switches between branched and unbranched morphologies), biogeography, and taxonomy of the group.

\section{MATERIALS AND METHODS}

Taxon sampling and morphological identification. We started with a set of $\sim 1,500$ samples of Cladophorales accumulated over several years, with specimens originating from all over the world, facilitated through the help of many generous colleagues. These specimens, either fresh, preserved in formalin or ethanol, or reconstituted from herbarium material, were examined with an Olympus SZX10 stereomicroscope and an Olympus BH2 light microscope (Olympus Optical Co. GmbH, Hamburg, Germany), and images were taken with a connected digital camera (ColorView Illu; Olympus Soft Imaging Systems, Münster, Germany). All specimens were identified morphologically (using mainly the following treatments: van den Hoek 1963, Söderström 1963, Sakai 1964, van den Hoek 1982, van den Hoek and Womersley 1984, van den Hoek and Chihara 2000, in addition to numerous local floras and taxonomic papers on Cladophora, Chaetomorpha, and Rhizoclonium (e.g., Koster 1955, Price 1967, Kornmann 1972, Nienhuis 1975, Abbott and Hollenberg 1976, Blair 1983, Santelices 1989, Stegenga et al. 1997, Kraft 2000, John et al. 2002, Leliaert and Coppejans 2003, Wehr and Sheath 2003, Boraso de Zaixso 2004, Alves et al. 2012). To visualize nuclei, filaments were stained with DAPI $(1.0 \mathrm{mM})$ after boiling for one minute. A subset of ca. 500 specimens was selected based on morphological identification and geographical occurrence for sequencing the LSU rDNA, resulting in 362 cladophoracean LSU sequences. From this, a new subset of 92 specimens for the final phylogenetic analyses was assembled (Table S2 in the Supporting Information), with most identical LSU sequences removed from the alignment (see Table S3 in the Supporting Information for excluded specimens with identical LSU sequences). If identical LSU sequences were linked to several morphospecies, they were retained in the alignment. For most of the specimens in this final dataset SSU rDNA sequences were generated (Table 1 and Table S2). The type species of the three currently recognized genera in the Cladophoraceae, Chaetomorpha, Cladophora, and Rhizoclonium, have been included in the dataset, namely Chaetomorpha melagonium (Weber \& Mohr) Kützing (see Silva 1950), Cladophora rivularis (see van den Hoek 1963), and Rhizoclonium riparium (Roth) Harvey (see Koster 1955, Price 1967), respectively. However, it has to be noted that in some clades, as for example the $R$. riparium clade and the freshwater Cladophora clade, it is impossible to assign names with confidence based on morphology due to the lack of diagnostic characters and therefore it is unknown which specimen might represent the type species. Species names have been placed in parentheses to indicate that those species epithets are not necessarily reliable: either the specimens had been already given that name, for example from a culture collection, a herbarium voucher or a morphological identification by a third party, or morphological identification at the species level was not possible due to the lack of reliable diagnostic characters. Species names that are deemed reliable or are at least the result of careful morphological identification are indicated in bold. Voucher specimens have been deposited at the National Museum of New Zealand Te Papa Tongarewa (WELT, see Table S2; herbarium abbreviation follow Thiers 2016).

Molecular markers and phylogenetic analyses. Most samples were preserved in silica gel for DNA extractions, but DNA was also extracted from ethanol-preserved or herbarium specimens. Total genomic DNA was isolated using the Chelex method (Goff and Moon 1993). Molecular phylogenetic analyses were based on nuclear-encoded small subunit (SSU) and partial large subunit (LSU) rDNA sequences. PCR amplifications were carried out with an initial denaturation step of $94^{\circ} \mathrm{C}$ for $5 \mathrm{~min}$ followed by 30-34 cycles of $1 \mathrm{~min}$ at $94^{\circ} \mathrm{C}, 1 \mathrm{~min}$ at $56^{\circ} \mathrm{C}-57^{\circ} \mathrm{C}$, and $1 \mathrm{~min}$ at $72^{\circ} \mathrm{C}$, and a final extension step of $5 \mathrm{~min}$ at $72^{\circ} \mathrm{C}$. The reaction volume was $25 \mu \mathrm{L}$ and consisted of $\sim 0.1-0.4 \mu \mathrm{g}$ genomic DNA, $1.25 \mathrm{nmol}$ of each dNTP, 6 pmol of each primer, $1 \times$ reaction buffer, $1-2.5 \mathrm{mM} \mathrm{MgCl}_{2}$, $5 \%$ bovine serum albumin, up to $5 \mu \mathrm{L}$ betaine, and one unit of Taq polymerase. The amounts of $\mathrm{MgCl}_{2}$ and betaine varied depending on the amplification success of particular specimens. The first $\sim 590$ nucleotides of the LSU rDNA were amplified using the universal primers C'1 forward and D2 reverse (Hassouna et al. 1984, Leliaert et al. 2003). About 1,700 bp of the SSU rRNA gene was amplified using the primer pairs SR1SS11H and SSU897-18SC2 (Leliaert et al. 2007). Amplifications were checked for correct size by electrophoresis on $1 \%$ agarose gels and subsequent staining with ethidium bromide. PCR products were purified with Montage PCR filter units (Millipore, Billerica, MA, USA) or with ExoSAP-IT ${ }^{\circledR}$ (USB Corporation, Cleveland, OH, USA) following the manufacturer's protocol. Cleaned PCR products were commercially sequenced 
TABLE 1. Specification of datasets, summary of models, and model parameters obtained.

\begin{tabular}{|c|c|c|c|}
\hline Alignment name & LSU & SSU & Concatenated $^{\mathrm{a}}$ \\
\hline Genes & Partial LSU & SSU & LSU-SSU \\
\hline Taxa & 108 & 111 & 111 \\
\hline $\begin{array}{l}\text { Ingroup taxa } \\
\text { (Cladophoraceae) }\end{array}$ & 92 & 95 & 95 \\
\hline Outgroup taxa & 16 & 16 & 16 \\
\hline $\begin{array}{l}\text { Alignment length/analysed } \\
\text { length }\end{array}$ & $690 / 666$ & $1,696 / 1,696$ & $2,384 / 2,362$ \\
\hline $\begin{array}{l}\text { Variable sites/parsimony } \\
\text { informative sites }\end{array}$ & $276 / 242$ & $297 / 230$ & $573 / 472$ \\
\hline Model estimated $^{\mathrm{b}}$ & $\mathrm{GTR}+\mathrm{I}+\mathrm{G}$ & $\mathrm{GTR}+\mathrm{I}+\mathrm{G}$ & $\mathrm{GTR}+\mathrm{I}+\mathrm{G}$ \\
\hline $\begin{array}{l}\text { Estimated base frequencies } \\
(\mathrm{A} / \mathrm{C} / \mathrm{G} / \mathrm{T})\end{array}$ & $0.21 / 0.24 / 0.33 / 0.22$ & $0.25 / 0.22 / 0.28 / 0.25$ & $0.23 / 0.23 / 0.29 / 0.25$ \\
\hline $\begin{array}{l}\text { Estimated substitution } \\
\text { frequencies }(\mathrm{AC} / \mathrm{AG} / \\
\mathrm{AT} / \mathrm{CG} / \mathrm{CT} / \mathrm{GT})^{\mathrm{b}}\end{array}$ & $0.84 / 3.42 / 2.20 / 0.71 / 6.36 / 1$ & $1.46 / 2.82 / 1.97 / 0.49 / 5.77 / 1$ & $1.05 / 3.12 / 1.92 / 0.76 / 6.10 / 1$ \\
\hline Among-site variation $I / G^{c}$ & $0.44 / 0.82$ & $0.73 / 0.53$ & $0.65 / 0.64$ \\
\hline
\end{tabular}

${ }^{a}$ The parameters estimated for the concatenated LSU-SSU dataset were not used in the phylogenetic analysis, instead the individual parameters estimated for the LSU and SSU datasets were used in the partitioned ML and BI analyses of the concatenated alignment.

${ }^{\mathrm{b}}$ Estimated by Akaike Information Criterion (AIC).

${ }^{c}$ Proportion of invariable sites (I) and gamma distribution shape parameter $(\mathrm{G})$ as estimated in PAUP/MrModeltest.

(Macrogen, Seoul, Korea). The obtained sequences have been deposited in GenBank (Tables S2 and S3).

Sixteen outgroup taxa of the Pseudocladophoraceae, the Pithophoraceae, and the Siphonocladus clade were used (see Boedeker et al. 2012). The 111 specimens used in the final phylogenetic analyses are listed in Table S2. The LSU and SSU sequences were aligned separately using MUSCLE (Edgar 2004) and then edited by eye in Se-Al v2.0a11 (Rambaut 2007). The alignment of two short variable regions of the LSU alignment ( $36 \mathrm{bp}$ in total) was ambiguous and was therefore excluded from all analyses. Separate alignments for both the LSU and the SSU sequences were created as well as a concatenated alignment of both markers (see Table 1 for details). Best-fit models of nucleotide substitution were determined by the Akaike Information Criterion for the two separate and concatenated alignments in PAUP* 4.0b10/Modeltest v3.7 (Posada and Crandall 1998, Swofford 2002), or in PAUP/MrModeltest2 v2.3 (Nylander 2004) for the use of MrBayes. Uncorrected and corrected pairwise distances were calculated in PAUP for the LSU and SSU datasets separately, with outgroup taxa in- or excluded, and plotted against each other to test for substitutional saturation.

Initial phylogenetic reconstructions consisted of the separate analysis of the LSU (92 sequences plus 16 outgroups) and SSU (95 sequences plus 16 outgroups) datasets. Subsequently the two markers were combined into a concatenated alignment, which was subsequently used for all analyses. This dataset was analysed with both maximum likelihood (ML) and Bayesian inference (BI) methodologies. Despite the same model of nucleotide evolution having been chosen for both the LSU and the SSU dataset (GTR + I + G, see Table 1), the model parameters (rate matrix, gamma shape, and proportion of invariant sites) differ considerably between LSU and SSU alignments (Table 1). Therefore, the concatenated dataset was partitioned into LSU and SSU, applying unlinked models to each partition.

ML analyses were performed using TreeFinder (Jobb 2011) and the reliability of the topologies was evaluated based on 1,000 nonparametric bootstrap replicates (Felsenstein 1985). BI was performed with MrBayes v3.1.2 (Ronquist and Huelsenbeck 2003) and consisted of two parallel runs of one cold and three incrementally heated chains each, and 6 million generations sampled every 100 generations. Posterior probabilities were obtained using a Metropolis-coupled Markov chain Monte Carlo approach. The average standard deviation of the split frequencies of the two parallel runs indicated that the tree samples became increasingly similar and that a stationary distribution was reached (split frequency $=0.0026)$. The $\log$ files of the runs were also checked with Tracer v1.4.1 (Rambaut and Drummond 2007), and a burning sample of 10,000 trees was removed from the 40,000 retained trees before calculating the majority rule consensus trees in MrBayes. The trees were visualized with FigTree v.1.2.2. (Rambaut 2008).

To evaluate alternative topologies regarding the placement of Ch. melagonium and Cladophora rupestris (L.) Kützing, two constrained Bayesian trees were generated. In the first constrained tree, Ch. melagonium and all other Chaetomorpha sequences formed a monophyletic group. In the second constrained tree, C. rupestris was placed in the Cladophora clade. These two topologies were compared with the result of our phylogenetic analysis by performing Approximately Unbiased (AU) tests (Shimodaira 2002) and Shimodaira-Hasegawa tests (SH; Shimodaira and Hasegawa 1999). For this, site-specific likelihoods for the unconstrained and the two constrained trees were calculated in PAML v4.3 (Yang 2007), and subsequently used as inputs in CONSEL v0.1i (Shimodaira and Hasegawa 2001).

\section{RESULTS}

Alignments. Details of the separate and concatenated alignments including number of ingroup and outgroup taxa, alignment length and estimated parameters of nucleotide substitution, are given in Table 1. Both saturation plots of the Cladophorales (ingroup and outgroup taxa, Fig. S1A in the Supporting Information) and the Cladophoraceae (ingroup only, Fig. S1B) leveled off with increasing genetic distance, indicating some saturation in both the SSU and the LSU data. 
Phylogenetic analyses. When the SSU and LSU datasets were analysed separately with $\mathrm{BI}$, the resulting trees were poorly resolved (data not shown) and any topological differences between the trees were in unsupported branches. The concatenated SSULSU alignment was found to perform much better in terms of support than the separate analyses. BI and ML analyses of the concatenated, partitioned alignment yielded highly similar tree topologies with comparable node support. The trees from these analyses had a well-supported backbone, including moderate to high support for almost all main clades. The phylogenetic tree obtained from the BI analysis of the concatenated, partitioned alignment is shown in Figure 2 with indication of BI posterior probabilities as well as ML bootstrap values of the main clades.

Phylogenetic relationships within the Cladophoraceae. Within the Cladophoraceae, five main clades were recovered plus Ch. melagonium (Weber \& Mohr) Kützing as a separate lineage and C. rupestris without a supported affiliation (Fig. 2). The $\mathrm{SH}$ and AU tests showed that the alternative topologies, with either Ch. melagonium as part of the Chaetomorpha clade (-Ln likelihood: 16,285.88) or with C. rupestris as part of the Cladophora clade (-Ln likelihood: 16,311.59), were rejected (-Ln likelihood of unconstrained tree: 16,265.89, $P$-values $<0.05$ for both $\mathrm{SH}$ and AU). The well-supported five main clades are (i) the Longi-articulatae clade, (ii) a clade containing the Rhizoclonium africanum clade as well as unidentified "slippery green filaments" and the Willeella clade, (iii) Chaetomorpha, minus Ch. melagonium, (iv) the $R$. riparium clade, and (v) the true Cladophora clade consisting of a marine clade and a clade of several lineages of C. vagabunda (L.) C. Hoek s.l. that also includes the freshwater lineage of Cladophora. None of the three currently accepted genera Chaetomorpha, Cladophora, and Rhizoclonium were recovered as monophyletic, instead all three are polyphyletic (also indicated by color coding of the names in Fig. 2). While Chaetomorpha and Rhizoclonium are both represented by two independent lineages each, Cladophora consists of at least four lineages within the Cladophoraceae.

The Longi-articulatae clade is sister to the rest of the Cladophoraceae and consists mostly of branched species with an acropetal organization and very large cells (Fig. 1A). The next clade, sister to the remainder, contains: the $R$. africanum clade which is characterized by a Rhizoclonium-like morphology (Fig. 1, B and C); a clade including slippery, unbranched filaments; and the Willeella clade, which includes Cladophora ordinata (Børgesen) C. Hoek with characteristic opposite branching (Fig. 1D) and Cladophora montagneana Kützing. The unbranched Ch. melagonium (the type of the genus, see Silva 1950) was recovered separately from the Chaetomorpha clade, which contains all other Chaetomorpha species (examples shown in Fig. 1, E and F).
The $R$. riparium clade contains the type species of Rhizoclonium ( $R$. riparium (Roth) Harvey, see Koster 1955, Price 1967) and is thus the true Rhizoclonium clade. This true Rhizoclonium clade and the Cladophora clade have a sister relationship. The Cladophora clade consists of two main lineages: a marine clade (termed the "Cladophora albida/sericea clade," as in Bakker et al. 1994), and a well-supported clade of several unresolved lineages of marine and brackish water $C$. vagabunda s.l. This $C$. vagabunda clade also includes a monophyletic group of all freshwater $\mathrm{Cla}$ dophora samples. The C. albida/sericea clade represents a number of species with the typical branched Cladophora morphology (Fig. 1H). The freshwater clade contains the type species of Cladophora, C. rivularis (see van den Hoek 1963), and consists of closely related species with extensive morphological plasticity (Fig. 1L). C. rupestris was recovered separately from the Cladophora clade.

Main clades within the Cladophoraceae. The main clades that are illustrated as triangles in Figure 2 are described in more detail below, and also shown as separate figures (Figs. 3-6).

Longi-articulatae clade: Fifteen species were grouped together in the Longi-articulatae clade, of which three were not identified at the species level (Fig. 3). Most species are characterized by coarse, large-celled thalli (Fig. 1A) with strict acropetal growth and have traditionally been placed in the Cladophora section Longi-articulatae (van den Hoek 1963, 1982, van den Hoek and Chihara 2000). However, several species of this clade do not correspond to this morphology, namely the irregularly branched C. rhodolithicola Leliaert, the diminutive C. pygmaea Reinke, and the cushion-forming C. herpestica (Montagne) Kützing. Cladophora herpestica, was found to be polyphyletic with a specimen from Chile being sister to C. feredayi Harvey from New Zealand, and another specimen of $C$. herpestica from Japan being sister to an unknown species from Japan. The latter is only represented by an SSU sequence from GenBank, which had been given the name $C$. fasciculatus (Kjellman) Wille (Hanyuda et al. 2002). This must be a misidentification, as $C$. fasciculatus has characteristic morphological features of the Siphonocladus clade and it is regarded a synonym of Cladophoropsis sundanensis Reinbold (Leliaert and Coppejans 2006).

Rhizoclonium africanum and Willeella clade: This clade encompasses three lineages, the $R$. africanum clade, a clade of unidentified "slippery green filaments," and the Willeella clade (Fig. 4). The well supported $R$. africanum clade contains a well-supported lineage of $R$. africanum Kützing specimens that have a typical Rhizoclonium morphology of unbranched filaments that can produce short lateral rhizoids (Fig. 1, B and C). Several samples of R. africanum from as far apart as Tanzania, Tahiti, Kosrae (Micronesia) and Panama had identical LSU sequences (Fig. 4, Table S3). The clade also 


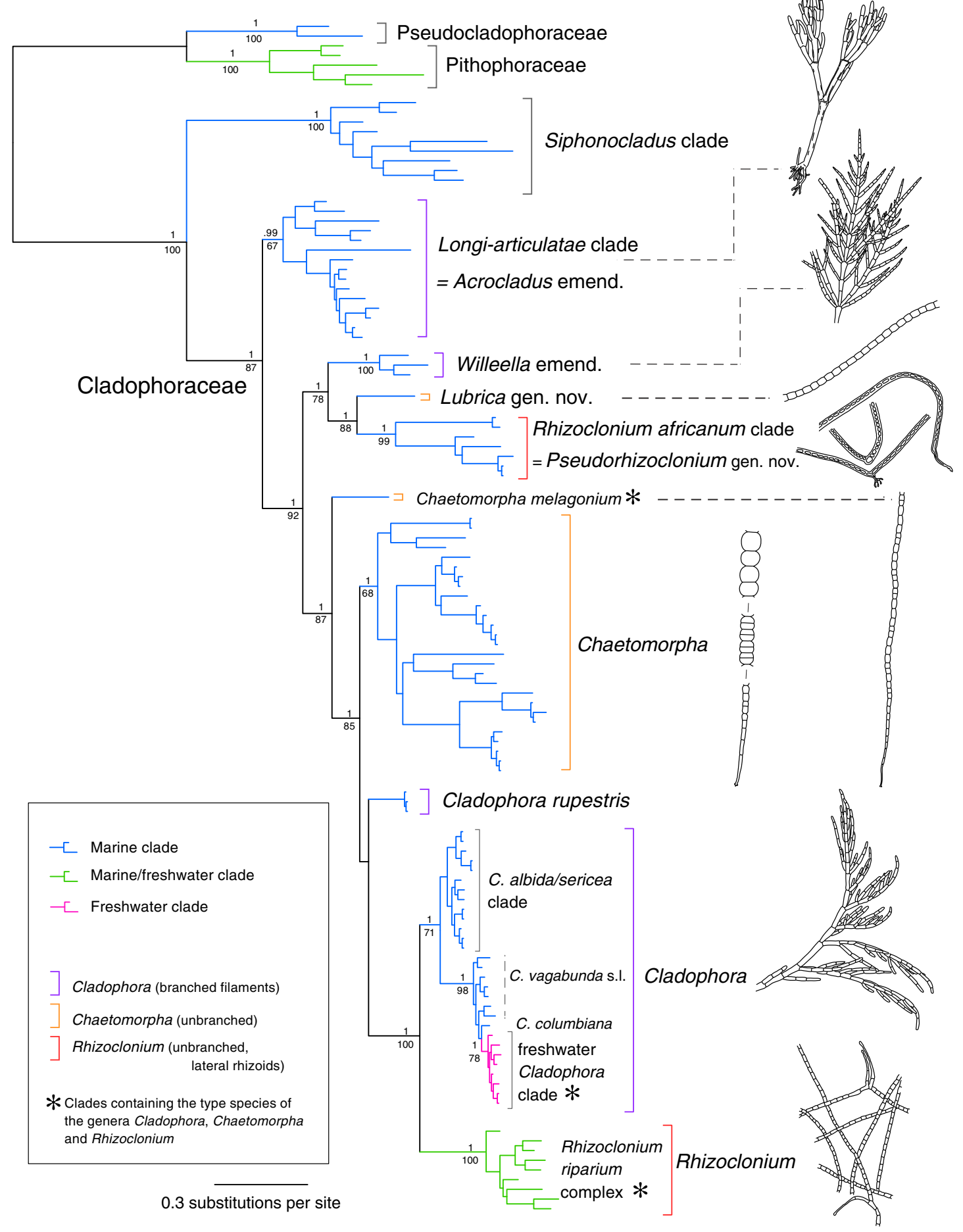

FIG. 2. Schematic of the Bayesian Inference (BI) phylogram inferred from rDNA small subunit (SSU) and partial large subunit (LSU) sequences of the Cladophorales with a focus on the family Cladophoraceae. Posterior probabilities from BI are indicated above branches, Maximum-likelihood bootstrap values (1,000 replicates) are given below the branches. Only bootstrap values above $50 \%$ and posterior probabilities above 0.95 are shown. Pithophoraceae and Pseudocladophoraceae were used as outgroups. The brackets next to the clades of the Cladophoraceae are color-coded according to generic names and branching patterns, to highlight polyphyly. The clades containing the type species of the genera Chaetomorpha, Cladophora, and Rhizoclonium are marked by an asterisk. The color of the branches represents marine (blue), freshwater (pink), or a mixture of marine and freshwater (green) species/habitats. Examples of typical morphologies are given as line drawings for each clade: Longi-articulatae clade: Cladophora dotyana (from van den Hoek and Chihara 2000), Willeella: Willeella ordinata (from van den Hoek and Rios 1972), Lubrica: Lubrica zinkwasii, Rhizoclonium africanum clade: Rhizoclonium africanum (from Sartoni 1992), Chaetomorpha melagonium (from Coppejans 1995), Chaetomorpha: Chaetomorpha coliformis (from Womersley 1984), Cladophora: Cladophora vagabunda (from van den Hoek 1963), Rhizoclonium: Rhizoclonium riparium (from Coppejans 1995). 


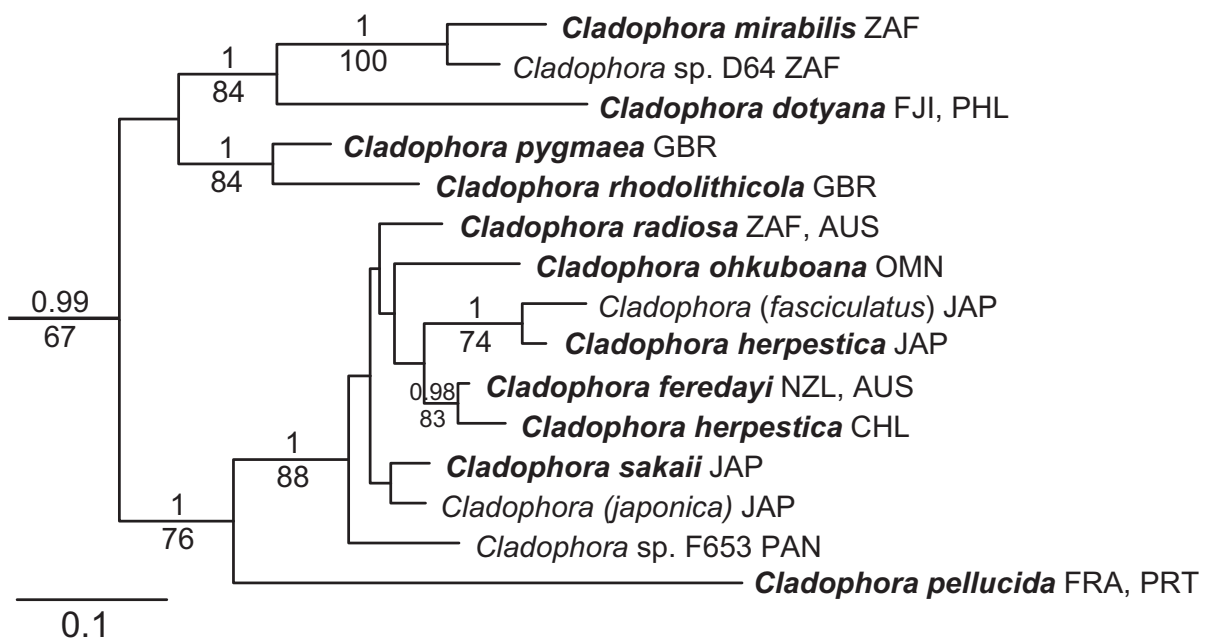

Fig. 3. Close-up of the Longi-articulatae clade (=Acrocladus emend.), cropped from the phylogram shown in Figure 2. Posterior probabilities from BI are indicated above branches, Maximum Likelihood (ML) bootstrap values (1,000 replicates) are given below the branches. Only bootstrap values above $50 \%$ and posterior probabilities above 0.95 are shown. Names in parentheses indicate that the species names are not necessarily reliable: either the specimens had been previously given that name, for example from a culture collection, or a herbarium voucher or a morphological identification by a third party; or morphological identification at the species level was not possible due to the lack of reliable diagnostic characters. If additional specimens had identical LSU rDNA sequences to those used in the phylogenetic reconstructions, their geographic origin and in some cases different species epithets were included. Countries of origin are abbreviated with ISO3166 codes as follows: AUS, Australia; CHL, Chile; FJI, Fiji; FRA, France; GBR, Great Britain; JAP, Japan; NZL, New Zealand; OMN, Oman; PAN, Panama; PHL, Philippines; PRT, Portugal; ZAF, South Africa.

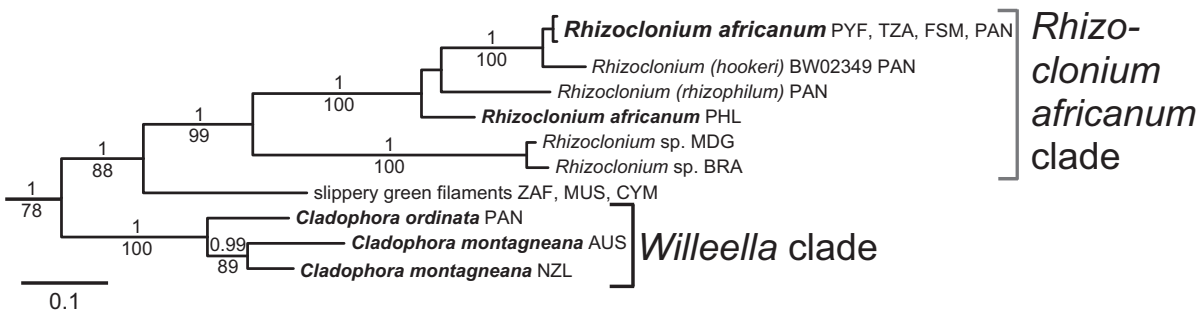

Fig. 4. Close up of the Rhizoclonium africanum clade (=Pseudorhizoclonium gen. nov.) and Willeella clade, cropped from the phylogram shown in Figure 2. Posterior probabilities from BI are indicated above branches, Maximum Likelihood (ML) bootstrap values (1,000 replicates) are given below the branches. Only bootstrap values above $50 \%$ and posterior probabilities above 0.95 are shown. Names in parentheses indicate that the species names are not necessarily reliable: either the specimens had been previously given that name, for example from a culture collection, or a herbarium voucher or a morphological identification by a third party; or morphological identification at the species level was not possible due to the lack of reliable diagnostic characters. If additional specimens had identical LSU rDNA sequences to those used in the phylogenetic reconstructions, their geographic origin and in some cases different species epithets were included. Countries of origin are abbreviated with ISO3166 codes as follows: AUS, Australia; BRA, Brazil; CYM, Cayman Islands; FSM, Federated States of Micronesia; MDG, Madagascar; MUS, Mauritius; NZL, New Zealand; PAN, Panama; PHL, Philippines; PYF, French Polynesia; TZA, Tanzania; ZAF South Africa.

encompasses another divergent lineage of two Rhizoclonium specimens from Madagascar and Brazil. The $R$. africanum clade as a whole is restricted to the tropics.

Sister to the $R$. africanum clade is a lineage of specimens that look like Chaetomorpha but that we are referring to as "slippery green filaments" (Fig. 4; Tables S2 and S3). This lineage is represented by four identical LSU sequences from South Africa, Mauritius and the Cayman Islands (Table S3; sample J08 from Grand Cayman is represented by a short LSU fragment of low sequence quality and might differ from the other three samples by $2 \mathrm{bp}$ ). Even though these unbranched specimens display a
Chaetomorpha-like morphology, they appeared instantly unique due to their striking smoothness and slipperiness, which was still apparent in the sheen of old herbarium specimens (specimens J06 and J08, see Table S3).

The Willeella clade is sister to the clade comprised of the slippery green filaments and the $R$. africanum clade (Fig. 4). This clade includes C. ordinata (Børgesen) C. Hoek and C. montagneana Kützing. C. ordinata has a unique morphology of mostly acropetal, opposite branching in one plane (Fig. 1D). C. montagneana does not share those morphological characteristics and has an irregular organization with long unbranched stretches particularly in 


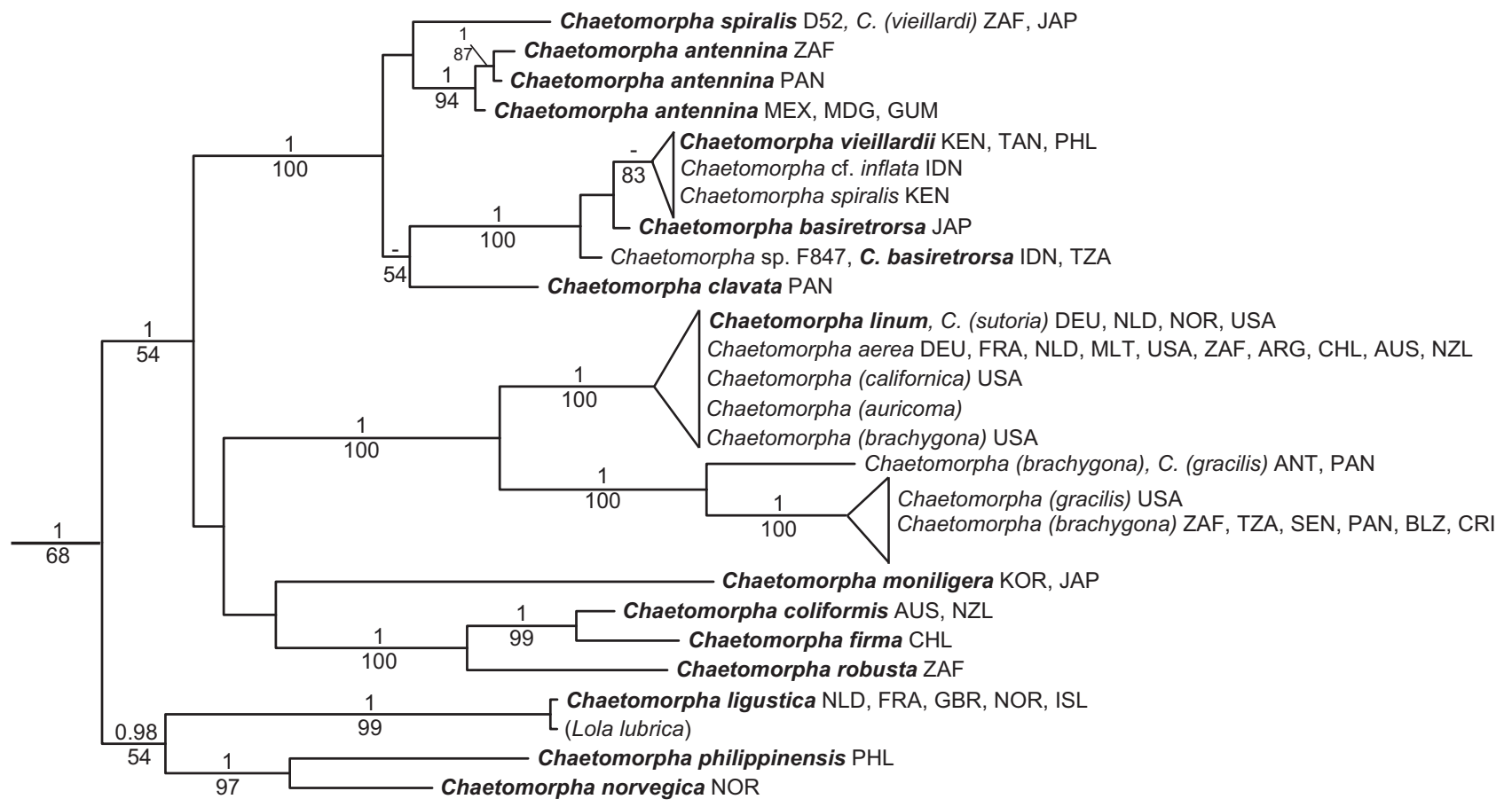

0.1

FIG. 5. Close up of the Chaetomorpha clade, cropped from the phylogram shown in Figure 2. Posterior probabilities from BI are indicated above branches, Maximum Likelihood (ML) bootstrap values (1,000 replicates) are given below the branches. Only bootstrap values above 50 and posterior probabilities above 0.95 are shown. Names in parentheses indicate that the species names are not necessarily reliable: either the specimens had been previously given that name, for example from a culture collection, or a herbarium voucher or a morphological identification by a third party; or morphological identification at the species level was not possible due to the lack of reliable diagnostic characters. If additional specimens had identical LSU rDNA sequences to those used in the phylogenetic reconstructions, their geographic origin and in some cases different species epithets were included. Countries of origin are abbreviated with ISO3166 codes as follows: ANT, Netherlands Antilles; ARG, Argentina; AUS, Australia; BLZ, Belize; CHL, Chile; CRI, Costa Rica; DEU, Germany; FRA, France; GBR, Great Britain; GUM, Guam; IDN, Indonesia; ISL, Iceland; JAP, Japan; KEN, Kenya; KOR, South Korea; MDG, Madagascar; MEX, Mexico; MLT, Malta; NLD, Netherlands; NOR, Norway; NZL, New Zealand; PAN, Panama; PHL, Philippines; SEN, Senegal; TZA, Tanzania; USA, United States of America; ZAF, South Africa.

apical parts, but can have occasional opposite branches. The large genetic distance between the specimen from Australia and New Zealand may indicate more than one species.

Chaetomorpha clade: All Chaetomorpha samples except the type species of the genus, Ch. melagonium and the "slippery green filaments" were recovered in this clade with moderate (ML) to good (BI) support (Fig. 5). The Chaetomorpha clade contains $\sim 20$ morphospecies that all have the typical Chaetomorpha morphology of unbranched, attached or unattached filaments without lateral rhizoids (Fig. 1, E and F). Several taxa were positioned on very long branches, especially Ch. moniligera Kjellman and Ch. ligustica (Kützing) Kützing (Fig. 5). Many Chaetomorpha are globally widespread, particularly Ch. aerea (Dilwyn) Kützing/Ch. linum, but also Ch. brachygona Harvey/ Ch. gracilis Kützing, Ch. antennina (Bory) Kützing, and Ch. viellardii (Kützing) M.J. Wynne (Fig. 5, Table S3 for the distribution of specimens with identical LSU sequences). An interesting biogeographical pattern is found in the subclade that comprises the three species with the largest cell diameters, namely Ch. coliformis (Montagne) Kützing (Fig. 1E) which occurs in Australia and New Zealand, Ch. robusta (Areschoug) Papenfuss from South Africa and Ch. firma Levring from Chile, reminiscent of a Gondwanan distribution pattern.

Cladophora and Rhizoclonium clade: In this clade, the genera Rhizoclonium and Cladophora are recovered as sister groups. Rhizoclonium is a widespread genus, with species from Asia, North and South America, Europe, Australia, and New Zealand (Fig. 6, Table S3). Within the Rhizoclonium clade, nine divergent lineages were recovered, each on a long branch, separated by up to $2.6 \%$ pairwise genetic distances between lineages. All displayed the typical Rhizoclonium morphology of thin unbranched filaments with or without lateral rhizoids (Fig. 1G), with filament diameters rarely exceeding $30 \mu \mathrm{m}$. Samples originated from marine, brackish and freshwater environments. Collections from freshwater were recovered in several lineages (specimens labeled "freshwater" and "R. hieroglyphicum" in Fig. 6). There was overlap in all 


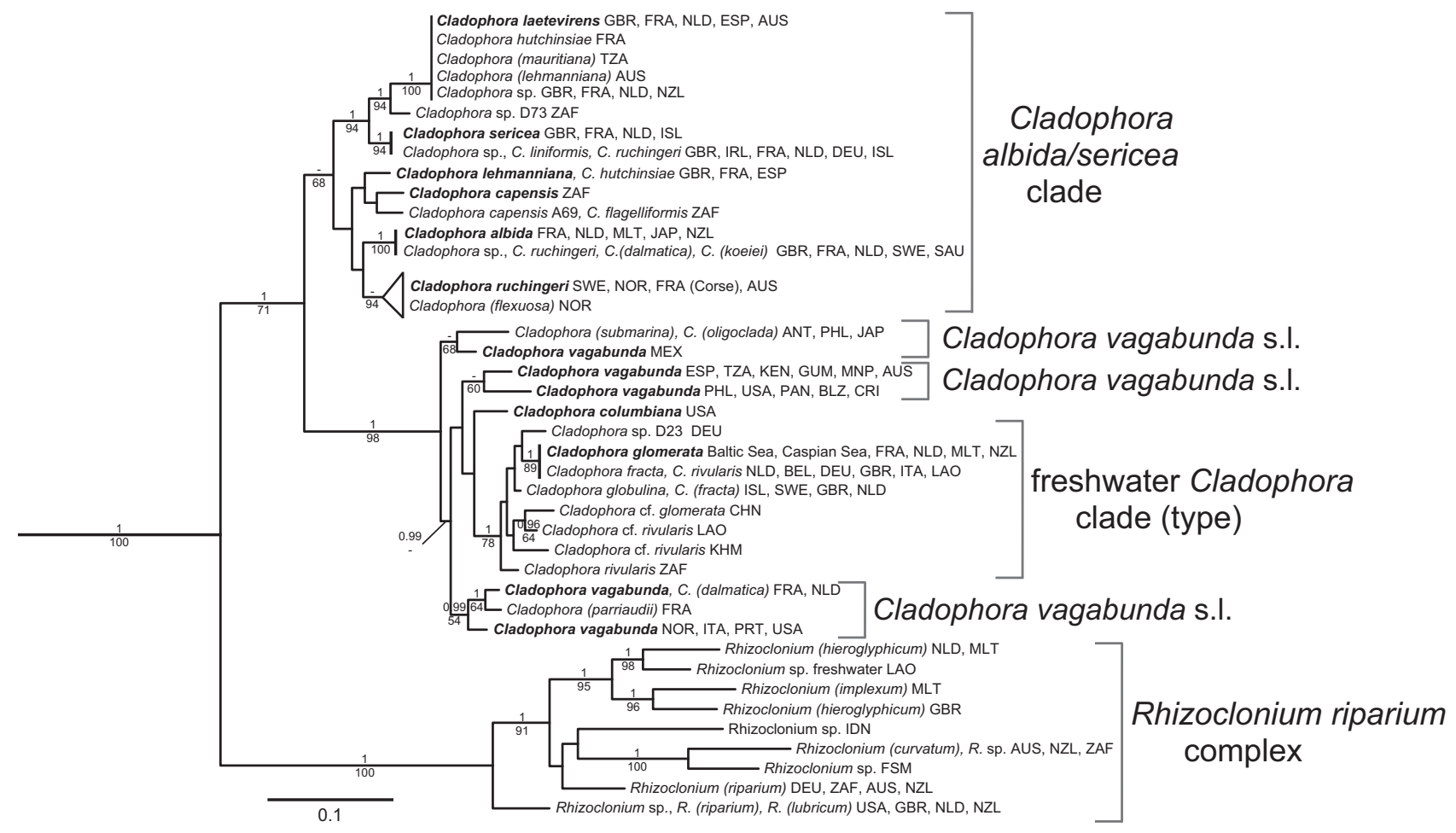

Fig. 6. Close up of the Rhizoclonium riparium and the Cladophora clade, cropped from the phylogram shown in Figure 2. Posterior probabilities from BI are indicated above branches, Maximum Likelihood (ML) bootstrap values (1,000 replicates) are given below the branches. Only bootstrap values above $50 \%$ and posterior probabilities above 0.95 are shown. Names in parentheses indicate that the species names are not necessarily reliable: either the specimens had been previously given that name, for example from a culture collection, or a herbarium voucher or a morphological identification by a third party; or morphological identification at the species level was not possible due to the lack of reliable diagnostic characters. If additional specimens had identical LSU rDNA sequences to those used in the phylogenetic reconstructions, their geographic origin and in some cases different species epithets were included. Countries of origin are abbreviated with ISO3166 codes as follows: ANT, Netherlands Antilles; AUS, Australia; BEL, Belgium; BLZ, Belize; CHN, China; CRI, Costa Rica; DEU, Germany; ESP, Spain; FRA, France; FSM, Federated States of Micronesia; GBR, Great Britain; GUM, Guam; IDN, Indonesia; ITA, Italy; IRL, Ireland; ISL, Iceland; JAP, Japan; KEN, Kenya; KHM, Cambodia; LAO, Laos; MEX, Mexico; MLT, Malta; MNP Northern Mariana Islands, NLD, Netherlands; NOR, Norway; NZL, New Zealand; PAN, Panama; PHL, Philippines; PRT, Portugal; SAU, Saudi Arabia; SWE, Sweden; TZA, Tanzania; USA, United States of America; ZAF, South Africa.

characters traditionally used for species identification such as filament width, cell length, and presence or absence of rhizoids between the lineages recovered in the molecular phylogeny. Because of this lack of truly diagnostic morphological features for Rhizoclonium, it is thus impossible to link existing species names to sequences (and no sequences are available for the type specimens). All species epithets in the Rhizoclonium clade are therefore given in parentheses, and represent names that either had been previously given to the specimens by a third party or have been traditionally used as for example $R$. hieroglyphicum for freshwater samples. While unreliable, these names have been retained here to demonstrate the difficulties in applying names in this clade. The individual lineages themselves can be widespread, for example the lineage that contains Rhizoclonium sp. USA is also found in New Zealand, Scotland and England as well as the Netherlands (Fig. 6; Table S3).

The Cladophora clade consists of two main lineages: the C. albida/sericea clade and one of several unresolved lineages of C. vagabunda s.l. that also includes a clade of all freshwater Cladophora samples (Fig. 6). All the members in this clade show the branched Cladophora morphology (e.g., Fig. 1, H$\mathrm{L}$ ), but almost unbranched forms can be found in the freshwater clade (Figs $1, \mathrm{~K}$ and $\mathrm{L}$ ). The C. albida/sericea clade is only poorly supported (not supported in BI, ML bootstrap value 68\%) and encompasses $\sim 12$ morphospecies (Fig. 6; Table S3), of which several are likely to be synonyms. Genetic divergence within this clade is rather low, with maximum $1 \%$ pairwise distances. While some species such as C. laetevirens (Dillwyn) Kützing and C. albida (Nees) Kützing are cosmopolitan (Table S3), some species such as the South African C. capensis (C. Agardh) De Toni have a restricted distribution. Morphological identification in this group is often unreliable (Table S3).

The well-supported C. vagabunda s.l. species complex consisted of four lineages of $C$. vagabunda and closely related marine species, whose phylogenetic relationships were not resolved, plus the freshwater Cladophora subclade (Fig. 6). Samples of the 
morphospecies C. vagabunda did not form a monophyletic group, and phylogenetically related taxa are C. submarina P. Crouan \& H. Crouan, C. columbiana F.S. Collins in Setchell \& N.L. Gardner, C. dalmatica Kützing and C.parriaudii C. Hoek. The genetic diversity within the C. vagabunda s.l. complex is comparable to what is found within the marine Cladophora clade (maximum $0.9 \%$ pairwise distances). Samples of C. vagabunda originated from Europe, Central and North America, Asia, Africa, Micronesia, and Australia (Table S3).

The freshwater Cladophora clade, which contains the type species $C$. rivularis, was well supported and contained the widespread, species C. glomerata (L.) Kützing, as well as C. rivularis, and C. globulina (Kützing) Kützing and C. fracta (O.F. Müller ex Vahl) Kützing (Fig. 6; Table S3). However, the freshwater representatives of Cladophora display the widest range of morphologies and specimens with identical LSU sequences can range from densely branched C. glomerata morphologies to almost unbranched C. rivularis morphologies, and the use of any species epithet in this clade is highly unreliable. Plasticity is not only extensive in the mode and extent of branching but also in cell dimensions (Fig. 1L). Genetic diversity in this clade is very low, with maximal $0.37 \%$ divergence. On the other hand, ribotypes can have huge distributions with identical LSU sequences originating from Europe, Kazakhstan, Laos, and New Zealand (Table S3).

Freshwater environments have been colonized twice independently in the Cladophoraceae, namely by the freshwater Cladophora species as well as by several Rhizoclonium lineages. Regarding the whole order Cladophorales, the marine-freshwater boundary has been crossed three times, as the family Pithophoraceae contains several freshwater genera (Fig. 2).

Many Cladophora species have been assigned to sections within the genus based on morphology. The proposed assignment to the various sections for the members of the Cladophora clades recovered in our phylogenetic analyses is shown in Table 2. None of the sections represents a monophyletic group.

\section{DISCUSSION}

Our study is the first comprehensive study using wide sampling and multiple markers, and resolves the main phylogenetic relationships with the Cladophoraceae. Our results lead to us proposing a new taxonomy and highlight areas that require further investigation.

The topology of the phylogeny presented here is in overall agreement with earlier studies (e.g., Hanyuda et al. 2002, Leliaert et al. 2003, 2009a,b, 2011a, Ichihara et al. 2013, Zhao et al. 2014), but differs by substantially increased taxon sampling. Since we sequenced a considerable amount of carefully selected and identified specimens from a wide geographical range (362 cladophoracean LSU sequences, see Tables S2 and S3), we are confident that our taxon sampling is a good representation of the diversity in the Cladophorales. It is also the first phylogeny of the Cladophoraceae that is based on more than one marker, yielding a generally well resolved phylogeny. As a result, our phylogeny reveals several novel relationships that were either not supported or not represented in taxon sampling in earlier studies.

Increased taxon sampling in this study led to the discovery of a new lineage (referred to as "slippery green filaments" in Figs. 2 and 4) that is described as a new genus below. Furthermore, we showed that all other Chaetomorpha species, except for the type species Ch. melagonium, form a monophyletic group. The $\mathrm{SH} / \mathrm{AU}$ tests showed that constraining Ch. melagonium in the Chaetomorpha clade resulted in a tree with significantly lower likelihood. Since the Chaetomorpha clade encompasses many species, of which many are widespread and well-known, we will propose to conserve Chaetomorpha against its type in a subsequent publication and to create a new genus to accommodate Ch. melagonium in the future. The morphologically distinct and common Atlantic species C. rupestris had been included in most earlier molecular phylogenetic studies of the Cladophoraceae (Leliaert et al. 2003, 2009a,b, Hayakawa et al. 2012, Ichihara et al. 2013), but just as in our phylogeny, the phylogenetic position of this species could not be resolved with certainty. However, it is demonstrated here for the first time with extended taxon sampling and good support that C. rupestris is not part of the true Cladophora clade (which encompasses the C. albida/sericea clade and the C. vagabunda clade that includes freshwater Cladophora and the type species). This was confirmed by the $\mathrm{SH} / \mathrm{AU}$ tests in which forcing C. rupestris in the Cladophora clade resulted in a tree with significantly lower likelihood. Therefore, C. rupestris should be transferred to a different genus, but this change is not proposed here as the phylogenetic position of C. rupestris was not resolved and as we are expecting additional taxon sampling and sequence data to resolve this.

Persistent problems in the taxonomy of the Cladophorales at the level of families, genera, and species have originated from the morphological simplicity with the associated lack of diagnostic characters and the large extent of phenotypic plasticity in relation to environmental conditions (van den Hoek 1963, Parodi and Cáceres 1993, see also Fig. 2, B, C, L). Since molecular methods have been applied to study the evolutionary relationships of this group to inform the taxonomy, it has become obvious that the classification based on morphology does not lead to the recognition of natural groups (Bakker et al. 1994, Hanyuda et al. 2002, Leliaert et al. 2003). At present, there are no clear morphological characters that allow the separation of 
TABLE 2. List of Cladophora species used in this study with their assignment to phylogenetic clades and the section they had been placed in based on morphology.

\begin{tabular}{|c|c|c|}
\hline Taxa & Clade & Section \\
\hline $\begin{array}{l}\text { Cladophora } \\
\text { montagneana } \\
\text { Kütz. }\end{array}$ & Willeella & Rupestres ${ }^{\mathrm{a}}$ \\
\hline $\begin{array}{l}\text { Cladophora ordinata } \\
\text { (Børgesen) C. Hoek }\end{array}$ & Willeella & Willeella $^{\mathrm{a}, \mathrm{b}}$ \\
\hline $\begin{array}{l}\text { Cladophora battersii } \\
\text { C. Hoek }\end{array}$ & Longi-articulatae & Rupestres ${ }^{\mathrm{d}}$ \\
\hline $\begin{array}{l}\text { Cladophora dotyana } \\
\text { W.J. Gilbert }\end{array}$ & Longi-articulatae & $\begin{array}{l}\text { Longi- } \\
\text { articulatae }^{\mathrm{b}}\end{array}$ \\
\hline $\begin{array}{l}\text { Cladophora echinus } \\
\text { (Bias.) Kütz. }\end{array}$ & Longi-articulatae ${ }^{c}$ & Aegagropila ${ }^{\mathrm{d}}$ \\
\hline $\begin{array}{l}\text { Cladophora feredayi } \\
\text { Harv. }\end{array}$ & Longi-articulatae & $\begin{array}{l}\text { Longi- } \\
\text { articulatae }^{\mathrm{d}}\end{array}$ \\
\hline $\begin{array}{l}\text { Cladophora herpestica } \\
\text { (Mont.) Kütz. }\end{array}$ & Longi-articulatae & n.a. \\
\hline $\begin{array}{l}\text { Cladophora japonica } \\
\text { Yamada }\end{array}$ & Longi-articulatae & $\begin{array}{l}\text { Longi- } \\
\text { articulatae }^{\mathrm{b}}\end{array}$ \\
\hline $\begin{array}{l}\text { Cladophora mirabilis } \\
\text { (C. Agardh) } \\
\text { Rabenh. }\end{array}$ & Longi-articulatae & n.a. \\
\hline $\begin{array}{l}\text { Cladophora ohkuboana } \\
\text { Holmes }\end{array}$ & Longi-articulatae & $\begin{array}{l}\text { Longi- } \\
\text { articulatae }^{\mathrm{b}}\end{array}$ \\
\hline $\begin{array}{l}\text { Cladophora pellucida } \\
\text { (Huds.) Kütz. }\end{array}$ & Longi-articulatae & $\begin{array}{l}\text { Longi- } \\
\text { articulatae }^{\mathrm{d}}\end{array}$ \\
\hline $\begin{array}{l}\text { Cladophora } \\
\text { pellucidoidea } \\
\text { C. Hoek }\end{array}$ & Longi-articulatae ${ }^{\mathrm{c}}$ & $\begin{array}{l}\text { Longi- } \\
\text { articulatae }^{\mathrm{a}}\end{array}$ \\
\hline $\begin{array}{l}\text { Cladophora pygmaea } \\
\text { Reinke }\end{array}$ & Longi-articulatae & Chamaethamnion $^{\mathrm{a}, \mathrm{d}}$ \\
\hline $\begin{array}{l}\text { Cladophora radiosa } \\
\text { (Suhr) Kütz. }\end{array}$ & Longi-articulatae & n.a. \\
\hline $\begin{array}{l}\text { Cladophora } \\
\text { rhodolithicola } \\
\text { Leliaert }\end{array}$ & Longi-articulatae & n.a. \\
\hline $\begin{array}{l}\text { Cladophora sakaii } \\
\text { I.A. Abbott }\end{array}$ & Longi-articulatae & $\begin{array}{l}\text { Longi- } \\
\text { articulatae }^{\mathrm{b}}\end{array}$ \\
\hline $\begin{array}{l}\text { Cladophora rupestris } \\
\text { (L.) Kütz. }\end{array}$ & C. rupestris & Rupestres $^{\mathrm{a}, \mathrm{b}, \mathrm{d}}$ \\
\hline $\begin{array}{l}\text { Cladophora albida } \\
\text { (Nees) Kütz. }\end{array}$ & $\begin{array}{l}\text { Marine } \\
\text { Cladophora }\end{array}$ & $\begin{array}{l}\text { Rupestres } \\
\text { /Glom. }^{\mathrm{a}, \mathrm{d}}\end{array}$ \\
\hline $\begin{array}{l}\text { Cladophora capensis } \\
\text { (C. Agardh) } \\
\text { De Toni }\end{array}$ & $\begin{array}{l}\text { Marine } \\
\text { Cladophora }\end{array}$ & n.a. \\
\hline $\begin{array}{l}\text { Cladophora flexuosa } \\
\text { (O.F. Müller) Kütz. }\end{array}$ & $\begin{array}{l}\text { Marine } \\
\text { Cladophora }\end{array}$ & Glomeratae $^{\mathrm{b}}$ \\
\hline $\begin{array}{l}\text { Cladophora hutchinsiae } \\
\text { (Dillwyn) Kütz. }\end{array}$ & $\begin{array}{l}\text { Marine } \\
\text { Cladophora }\end{array}$ & $\begin{array}{l}\text { Rupestres }{ }^{\mathrm{d}} \\
\text { /Glom. }\end{array}$ \\
\hline $\begin{array}{l}\text { Cladophora laetevirens } \\
\text { (Dillwyn) Kütz. }\end{array}$ & $\begin{array}{l}\text { Marine } \\
\text { Cladophora }\end{array}$ & Glomeratae $^{\mathrm{a}, \mathrm{b}, \mathrm{d}}$ \\
\hline $\begin{array}{l}\text { Cladophora } \\
\text { lehmanniana } \\
\text { (Lindenb.) Kütz. }\end{array}$ & $\begin{array}{l}\text { Marine } \\
\text { Cladophora }\end{array}$ & Glomeratae $^{\mathrm{d}}$ \\
\hline $\begin{array}{l}\text { Cladophora ruchingeri } \\
\text { (C. Agardh) Kütz. }\end{array}$ & $\begin{array}{l}\text { Marine } \\
\text { Cladophora }\end{array}$ & $\begin{array}{l}\text { Rupestres }^{\mathrm{a}, \mathrm{d}} \\
\text { /Glom. }^{\mathrm{b}}\end{array}$ \\
\hline $\begin{array}{l}\text { Cladophora sericea } \\
\text { (Hudson) Kützing }\end{array}$ & $\begin{array}{l}\text { Marine } \\
\text { Cladophora }\end{array}$ & $\begin{array}{l}\text { Rupestres }^{\mathrm{a}, \mathrm{d}} \\
\text { /Glom. }^{\mathrm{b}}\end{array}$ \\
\hline $\begin{array}{l}\text { Cladophora columbiana } \\
\text { F.S. Collins }\end{array}$ & $\begin{array}{l}\text { C. vagabunda } \\
\text { s.l. }\end{array}$ & n.a. \\
\hline $\begin{array}{l}\text { Cladophora dalmatica } \\
\text { Kütz. }\end{array}$ & $\begin{array}{l}\text { C. vagabunda } \\
\text { s.l. }\end{array}$ & Glomeratae $^{\mathrm{a}, \mathrm{b}, \mathrm{d}}$ \\
\hline $\begin{array}{l}\text { Cladophora parriaudii } \\
\text { C. Hoek }\end{array}$ & $\begin{array}{l}\text { C. vagabunda } \\
\text { s.l. }\end{array}$ & Glomeratae $^{\mathrm{d}}$ \\
\hline
\end{tabular}

(continued)
TABLE 2. (continued)

\begin{tabular}{lll}
\hline \hline Taxa & \multicolumn{1}{c}{ Clade } & \multicolumn{1}{c}{ Section } \\
\hline Cladophora submarina & C. vagabunda & Xanthochlora $^{\mathrm{a}}$ \\
P. Crouan \& & s.l. & \\
H. Crouan & & \\
Cladophora vagabunda & C. vagabunda & Glomeratae $^{\mathrm{a}, \mathrm{b}, \mathrm{d}}$ \\
(L.) C. Hoek & s.l. & \\
Cladophora globulina & $\begin{array}{c}\text { Freshwater } \\
\text { (Kütz.) Kütz. }\end{array}$ & Cladophora $^{\mathrm{a}, \mathrm{d}}$ \\
Cladophora glomerata & Freshwater & Glomeratae $^{\mathrm{d}}$ \\
(L.) Kütz. & Cladophora & \\
Cladophora rivularis & Freshwater & Cladophora $^{\mathrm{d}}$ \\
(L.) C. Hoek & Cladophora & \\
\hline
\end{tabular}

${ }^{a}$ van den Hoek (1982).

ban den Hoek and Chihara (2000).

shown to be part of the Longi-articulatae clade in Leliaert et al. (2009b).

dvan den Hoek (1963).

n.a. not assigned.

lineages in the Cladophoraceae consistent with phylogenetic relationships, and molecular sequences provide useful and straightforward data to recognize genera and species. The two genera newly described in this study (Pseudorhizoclonium \& Lubrica) are recognized entirely based on molecular data, as has the placement of some taxa within the two re-established genera (e.g., the placement of $C$. montagneana in the Willeella clade (= Willeella emend.), or the placement of the morphologically aberrant C. battersii, C. echinus, C. herpestica, C. rhodolithicola, and C. pygmaea in the Longi-articulatae clade (= Acrocladus emend.)). The description of higher-order taxa in algae based on DNA sequences in the absence of unique morphological characters is not new (e.g., Nelson et al. 2005, West et al. 2008, Sutherland et al. 2011). The recognition of taxa based on DNA sequence data is becoming especially common at the species level as more and more cryptic species are discovered (Bakker et al. 1995, van der Strate et al. 2002, Leliaert et al. 2009c, 2014, Jörger and Schrödl 2013, Payo et al. 2013, Muangmai et al. 2014, West et al. 2014, see also De Clerck et al. 2013). In morphologically simple organisms, such as for example in the genetically diverse genus Rhizoclonium, or the Cladophorales in general, there is a limit to the number of species that can have a unique morphology and that can be successfully diagnosed morphology (Verbruggen 2014).

More than 12 sections had been created within the genus Cladophora, based on architectural types, which played an important part in re-organizing the taxonomy of this large genus by re-evaluating morphological characters and their plasticity and by utilizing culturing techniques (see van den Hoek 1963, 1982, van den Hoek and Chihara 2000, but sections within Cladophora had also been created by Kützing 1843, 1849, Hansgirg 1886, Brand 1909, 
Hamel 1924, Sakai 1964, Skabichevsky 1976). However, molecular studies have shown that not only the genus Cladophora but also the sections within the genus are polyphyletic (Bakker et al. 1994, Hanyuda et al. 2002, Leliaert et al. 2003, see also Table 2). One morphological character that consistently played an important role in the subgeneric classification of Cladophora is the mode of thallus growth: exclusively or mainly acropetal, or mainly by intercalary cell divisions. This character turns out to be of limited taxonomic value. Even in one of the morphologically best defined natural groups with a Cladophora morphology, the Longi-articulatae clade, acropetal organization is not exclusive despite being a defining character of the section. Species such as C. glomerata illustrate the plasticity of this character as specimens in turbulent waters grow mainly acropetally while unattached and quiet water forms grow mainly intercalary (see van den Hoek 1963).

While this study focuses on generic and interspecific relationships within the Cladophoraceae rather than species level taxonomy, it is apparent from our molecular data (and Table S3) that accurate species identification based on morphology is problematic. A good example is the Rhizoclonium clade, where the under-appreciation of phenotypic plasticity, ecological width within species, and distribution ranges led to the description of more than 70 taxa (Guiry and Guiry 2015), while at the same time cryptic species exist (see Fig. 6, Table S3 and discussion above, also Leliaert and Boedeker 2007, Ichihara et al. 2013). More variable markers such as the internally transcribed spacers of the rRNA cistron (ITS) might be useful in detecting even more hidden diversity, despite potential problems concerning intraindividual variation in the ITS region (Famà et al. 2000, 2002). Generally, the analysis of multiple loci in the Cladophorales is problematic due to amplification problems of organellar DNA (as yet it has been impossible to amplify chloroplast or mitochondrial DNA, e.g., Furumoto 2009, Verbruggen et al. 2009, Saunders and Kucera 2010) and single-copy nuclear loci (as a consequence of the limited availability of genomic data for Chlorophyta and the frequency of large introns in their genes). One of the challenges will be to connect previously described taxa to evolutionary lineages in order to decide on species epithets and synonyms, for which diagnostic characters are needed. Different approaches are possible, either the designation of epitypes for which sequence data are available, or the synonymization of existing names and subsequent detection of cryptic lineages, possibly without formal description. Technological advances such as next generation sequencing allow the generation of at least partial DNA sequences of old type specimens, even if the DNA is considerably degraded (Hughey et al. 2014, Prosser et al. 2016). Limiting factors might be time and financial constraints, particularly in a group such as the Cladophorales with so many synonyms, and hence such a large number of theoretically available names and type specimens to sequence. Furthermore, the preservation method and quality of the DNA of the type specimens, as well as the requirement for destructive sampling of precious type material, might prevent the application of this promising approach.

Many taxonomic changes at the species level are also required in the C. albida/sericea and C. vagabunda clades as well as in the freshwater subclade, the Chaetomorpha clade, and the Rhizoclonium clade. In the absence of diagnostic characters, as it appears to be the case in the Rhizoclonium clade, it will very difficult to link the different species lineages to existing names (see Tautz et al. 2003, De Clerck et al. 2013, Verbruggen 2014).

In addition to the pronounced phenotypic plasticity in the Cladophoraceae, the extent of convergent evolution leading to similar phenotypes in distantly related lineages is another striking observation in this group. There have been at least three independent switches between branched and unbranched morphologies (see Fig. 2), similar to the multiple switches between tubular and bladed morphologies in Ulva (Hayden et al. 2003) and between filamentous and bladed morphologies in the Bangiales (Sutherland et al. 2011). Unbranched morphologies are found in the lineage including the $R$. africanum clade, Ch. melagonium, the Chaetomorpha clade, and the $R$. riparium clade. While the genus Rhizoclonium is generally regarded as unbranched, recently the placement of two branched species, $R$. pachydermum Kjellmann and $R$, ramosum Z. Zhao \& G. Liu, within the $R$. riparium clade has been shown with LSU and SSU rDNA sequences (Zhao et al. 2014, Zhao et al. 2016). Many lineages of Rhizoclonium can produce short lateral rhizoids. Only a few species of Chaetomorpha also produce such lateral rhizoids, including Chaetomorpha basiretrorsa Setchell (the currently accepted name for Rhizoclonium grande Børgesen, see N'Yeurt and Payri 2007). In addition, Ch. antennina (Bory de Saint-Vincent) Kützing can produce lateral branches in culture (Leliaert et al. 2011b), further blurring the morphological concept of the genus Chaetomorpha.

The Chaetomorpha clade is the clade with fewest number of morphological characters available for species delimitation, nonetheless, 120 taxa have been described (Guiry and Guiry 2015). It is apparent from Figure 5 and especially from Table S3 that a lot of work still needs to be done to sort out the species level taxonomy of Chaetomorpha properly, which will involve a considerable collecting and sequencing effort to figure out morphological ranges, distributions, and intraspecific variation and finally useful names and synonyms, as well as a detailed survey (and ideally sequencing) of type material to sort out the nomenclature. The lineage containing Ch. aerea, Ch. linum, Ch. gracilis, and 
Ch. brachygona (Fig. 5) is a taxonomic nightmare, not unlike the $R$. riparium complex, with only few, but extensively, overlapping morphological characters but plenty of described species names available (see Table S3 for just a few synonyms). Another example of a problematic species in this clade is Ch. spiralis Okamura, as this morphologically unique species appears to represent more than one species genetically (Fig. 5). Chaetomorpha is a genus that is frequently causing green tides in different parts of the world (e.g., Flindt et al. 1997, Deng et al. 2013, Zhang et al. 2014), and the relationships between unattached and attached growth forms and species also remain poorly understood to date (see Christensen 1957, Kornmann 1972, Blair et al. 1982, Leliaert and Boedeker 2007), and thus it would be important to gain a better understanding of the species level taxonomy from both an ecological and management perspective.

The true Cladophora clade gave rise to a monophyletic freshwater lineage, which together with the lineages of the marine/brackish morphospecies C. vagabunda s.l. is sister to a complex of closely related marine species. The same relationships have been inferred by Hayakawa et al. (2012) based on ITS rDNA sequences. The essentially marine species C. vagabunda penetrates into brackish waters with salinities as low as $15 \mathrm{psu}$. It had been shown in earlier studies that $C$. vagabunda contains several cryptic species (e.g., Bakker et al. 1995, van den Hoek and Chihara 2000, Gestinari et al. 2009, Hayakawa et al. 2012). In our phylogenetic reconstructions, four lineages were grouped together with the freshwater clade (Fig. 6), of which three contained specimens identified as C. vagabunda, but also included C. submarina, C. columbiana, C. dalmatica, and C. parriaudii. The latter two species are also known to occur in brackish waters, the former two occur in the intertidal. ITS sequences are likely to resolve the relationships of these lineages and assess the status of those listed species names (Hayakawa et al. 2012). The species in the C. albida/sericea clade are mainly distributed in the intertidal, an environment that experiences extreme fluctuations in environmental conditions and that requires acclimatization mechanisms to cope with varying salinities, just like the $C$. vagabunda lineages. This invites for speculating that the ancestor of the freshwater clade was an intertidal organism, pre-adapted to osmoregulation that allowed easier colonization of freshwater environments. Also the sister lineage to Cladophora, the $R$. riparium complex (see Fig. 6) has stunning osmoregulation capacities. It has been shown that Rhizoclonium can tolerate great fluctuations in salinity (Nienhuis 1975, Imai et al. 1997, Matsuyama-Serisawa et al. 2004). Several of the lineages shown in Figure 6 have been collected in freshwater environments, and several more in brackish waters, thus it is a possibility that not only the ancestor of Rhizoclonium but also the ancestor of the Cladophora/
Rhizoclonium clade was adapted to salinity changes and possibly an intertidal organism.

In conclusion, it is obvious that taxonomic changes are required, as the taxonomy needs to reflect evolutionary history and polyphyletic genera are not acceptable, thus the description of three new genera (see below). Ideally, the current phylogenetic hypothesis should be verified by one or more independent molecular marker, as to date, all phylogenies of the Cladophorales are based on nuclear ribosomal DNA sequences. While this study had more extensive taxon sampling than earlier works, there are still dozens if not hundreds of described species of Cladophora and Chaetomorpha that remain to be sequenced. Nonetheless, progress has been made here with the taxonomy at the genus level which will hopefully facilitate communication and subsequent diversity and systematic studies that focus more at the species level.

\section{TAXONOMIC TREATMENT}

Longi-articulatae clade: most species in this clade have large, coarse thalli (Cladophora mirabilis (C. Agardh) Rabenhorst can be up to $1 \mathrm{~m}$ long) consisting of acropetally organized branch systems (see Table S4) that grow almost exclusively by division of apical cells with subsequent cell elongation and enlargement (see Figs. 1A, 7, A-C). The species with this mode of growth have conspicuous stipes that consist of one to three very large cells and are attached by branched rhizoids developing from the basal cell. This is the typical morphology that the section Longi-articulatae Hamel was based on (see van den Hoek 1963, 1982, van den Hoek and Chihara 2000). However, a few species of this clade do not correspond to this morphology, namely the irregularly branched C. rhodolithicola Leliaert (Fig. 7E), the cushion-forming C. herpestica (Montagne) Kützing with reduced branch formation, but also C. echinus Biasoletto that has a morphology similar to Aegagropila linnaei Kützing (Fig. 7F), the diminutive C. pygmaea Reinke (Fig. 7G), and C. battersii $\mathrm{C}$. Hoek that forms aegagropiloid aggregates composed of irregularly organized branch systems (van den Hoek 1963, Leliaert and Boedeker 2007). Both C. echinus and C. battersii had been placed in the Longi-articulatae clade based on molecular data in an earlier study (Leliaert et al. 2009b). The placement of these unusual morphologies within the Longi-articulatae clade illustrates the importance of molecular data for understanding evolutionary relationships. In addition to the pronounced tendency for acropetal organization and conspicuous basal stipes, there is also a striking tendency for members of this clade to occupy subtidal habitats (see Table S4). This clade received good statistical support also in other molecular studies (Hanyuda et al. 2002, Leliaert et al. 2009b, Ichihara et al. 2013), and we re-establish the genus Acrocladus C. Nägeli 
here (see below). In addition to the species that were included in our phylogenetic analyses we transfer the species to this new genus that had been shown earlier to belong to this clade, C. echinus, C. batersii C. Hoek, and C. pellucidoidea C. Hoek (Leliaert et al. 2009b), but also the following members of the section Longi-articulatae for which we are currently lacking sequence data because they have the typical morphology: C. longicellulata C. Hoek, C. minisakaii C. Hoek \& Chihara, C. bainesii Müller \& Harvey ex Harvey, C. pseudobainesii C. Hoek \& Searles, C. feredayoides Kraft \& Millar. A number of additional species that had been assigned to the section Longi-articulatae will not be transferred to the new genus Longiarticulata as their phylogenetic position is uncertain and we choose to await DNA sequences, namely C. blomquistii C. Hoek, C. conferta P. Crouan \& H. Crouan, C. nigrescens Zanardini ex Frauenfeld C. prolifera (Roth) Kützing C. pseudostruveoides Kraft \& Millar, C. retroflexa (Bonnemaison ex P. Crouan \& H. Crouan) Hamel, C. stimpsonii Harvey, and C. wrightiana Harvey.

The type species of the section Longi-articulatae is C. pellucida (van den Hoek 1963), of which Acrocladus mediterraneus Nägeli is a synonym (Cormaci et al. 2014) and therefore the genus Acrocladus is reestablished here for the Longi-articulatae clade.

Acrocladus C. Nägeli emend. Boedeker

Description: Marine algae with bright to dark green thalli, consisting of thick-walled, uniseriate filaments; thalli either coarse with more or less acropetally organized branch systems arising from pseudodichotomously or pseudotrichotomously (Fig. 7, A-D) branching main axes that are attached to the substratum by rhizoids produced at the basal pole of a long basal cell that is part of a conspicuous basal stipe, or thalli coarse, attached to the substrate by unbranched, aseptate rhizoids developing from the proximal pole of intercalary and apical cells (Fig. 7, E and F), or thalli diminutive, less than $2 \mathrm{~mm}$ tall, attached by a disciform holdfast to sand grains (Fig. 7G), or thalli forming unattached aegagropiloid aggregates hooked around Zostera rhizomes in sheltered bays.

Type species: Acrocladus pellucidus (Hudson) Boedeker comb. nov. Basionym: Conferva pellucida Hudson 1762. Fl. Angl., J. Nourse et C. Moran, London: 483.

Holotype: Walney Island, Lancashire, England (Silva et al. 1996); type specimen: neotype in BM (van den Hoek 1963).

Synonyms: Acrocladus mediterraneus C. Nägeli Aegagropila trichotoma (C.Agardh) Kützing, Chloronitum pellucidum (Hudson) Gallion, Cladophora catenifera Kützing, Cladophora pellucida (Hudson) Kützing, Cladophora pseudopellucida C. Hoek, Cladophora trichotoma (C.Agardh) Kützing, Conferva pellucida Hudson, Conferva trichotoma C.Agardh,

Acrocladus bainesii (Müller \& Harvey ex Harvey) Boedeker comb. nov.
Basionym: Cladophora bainesii Müller \& Harvey ex Harvey. 1859. Phycologia Australica. Vol. 2. Lovell Reeve \& Co, London, pl. 112.

Acrocladus battersii (C. Hoek) Boedeker comb. nov.

Basionym: Cladophora battersii C. Hoek 1963. Revision of the Europeam species of Cladophora. E. J. Brill, Leiden, p. 92-93, figs 317-322.

Acrocladus dotyanus (W.J. Gilbert) Boedeker comb. nov.

Basionym: Cladophora dotyana W.J. Gilbert 1965. Contribution to the marine Chlorophyta of Hawaii, II. Pacific Science 19, p. 486-489.

Acrocladus echinus (Biasoletto) Boedeker comb. nov.

Basionym: Conferva echinus Biasoletto 1841. Relazione del viaggio fatto nella primavera dell'anno 1838 dalla Maestà del Re Federico Augusto di Sassonia nell'Istria, Dalmazia e Montenegro. Presso H. J. Favarger, Trieste, p. 202.

Acrocladus feredayi (Harvey) Boedeker comb. nov.

Basionym: Cladophora feredayi Harvey 1858. Phycologia Australica. Vol. 1. Lovell Reeve \& Co, London, pl. 47.

Acrocladus feredayoides (Kraft \& Millar) Boedeker comb. nov.

Basionym: Cladophora feredayoides Kraft \& Millar ex Kraft 2000. Marine and estuarine benthic green algae (Chlorophyta) of Lord Howe Island, southwestern Pacific. Australian Systematic Botany 13, p. 556, fig. 19A-F.

Acrocladus herpesticus (Montagne) Boedeker comb. nov.

Basionym: Conferva herpestica Montagne 1842. Prodromus generum specierumque phycearum novarum. Paris, p. 15 .

Acrocladus japonicus (Yamada) Boedeker comb. nov.

Basionym: Cladophora japonica Yamada 1931. Notes on some Japanese algae II. Journal of the Faculty of Science, Hokkaido Imperial University Ser. 5, 1, p. 65, pl. 16.

Acrocladus longicellulatus (C. Hoek) Boedeker comb. nov.

Basionym: Cladophora longicellulata C. Hoek 1969. Notes on Cladophora (Chlorophyceae). I. Two new Caribbean species: Cladophora jongiorum nov. sp. and Cladophora longicellulata nov. sp. Journal of Phycology 5 (2), p. 131-132, figs 7-11.

Acrocladus minisakaii (C. Hoek \& Chihara) Boedeker comb. nov.

Basionym: Cladophora minisakaii C. Hoek \& Chihara 2000. Taxonomic revision of the marine species of Cladophora (Chlorophyta) along the coasts of Japan and the Russian Far-east. National Science Museum (Tokyo) Monographs 19. National Science Museum, Tokyo, Japan, p. 108-109, figs 48A,C, 49.

Acrocladus mirabilis (C. Agardh) Boedeker comb. nov. 

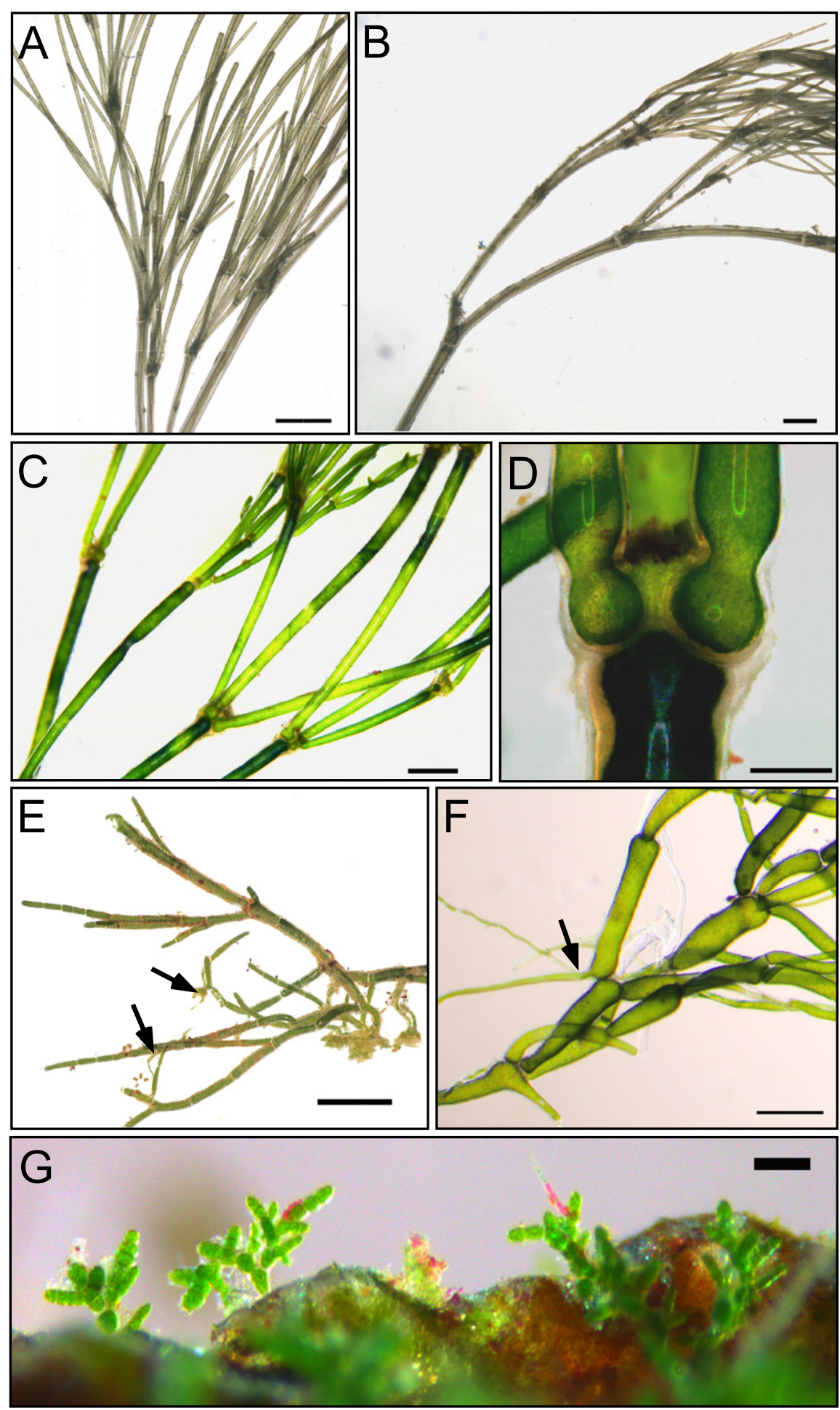

FIg. 7. Morphological diversity in Acrocladus emend. (A-D) Typical morphologies of the former section Longi-articulatae. (E-G) Examples of atypical morphologies. (A) Densely branched apical part of A. radiosus from Australia with acropetal organization (specimen GENT: HV2202), scale bar $=50 \mu \mathrm{m}$. (B) Long cells in lower parts of thallus in A. radiosus (specimen GENT: HV2202), scale bar $=1 \mathrm{~mm}$. (C) Pseudotrichotomously branching main axes with long cells in A. pellucidus from Northern Ireland (image modified from Leliaert and Boedeker 2007), scale bar $=1 \mathrm{~mm}$. (D) Detail of branching main axis showing constrictions above the joints of side branches in A. pellucidus (image modified from Leliaert and Boedeker 2007), scale bar $=200 \mu \mathrm{m}$. (E) Irregularly branched, creeping, stolonoid filaments with secondary rhizoids produced from the basal poles of the cells (arrows) in A. rhodolithicolus from subtidal maerl beds in Wales (specimen GENT: Bunker1, image modified from Leliaert et al. 2009b), scale bar $=500 \mu \mathrm{m}$. (F) Irregularly branched filaments with aseptate secondary rhizoids produced at the basal pole of intercalary cells (arrow) in a culture of A. echinus in a culture of material from Algeria, scale bar $=500 \mu \mathrm{m}$. $(\mathrm{G})$ Habit of miniscule thalli of $A$. pygmaeus growing on a small stones, Wales (specimen L: 0793569), scale bar $=500 \mu \mathrm{m}$. 
Basionym: Conferva mirabilis C. Agardh 1820. Icones algarum ineditae. Vol. Fasc. 1. Officina Berlingiana, Lund, pl. IX.

Acrocladus ohkuboanus (Holmes) Boedeker comb. nov.

Basionym: Cladophora ohkuboana Holmes, 1895. Marine algae from Japan. Journal of the Linnean Society of London, Botany 31, p. 249.

Acrocladus pellucidoideus (C. Hoek) Boedeker comb. nov.

Basionym: Cladophora pellucidoidea C. Hoek 1982. A taxonomic revision of the American species of Cladophora (Chlorophyceae) in the North Atlantic Ocean and their geographic distribution. North-Holland Publishing Company, Amsterdam, Oxford, New York, p. 179180, figs 358-359.

Acrocladus pseudobainesii (C. Hoek \& Searles) Boedeker comb. nov.

Basionym: Cladophora pseudobainesii C. Hoek \& Searles 1988. Cladophora pseudobainesii nov. spec. (Chlorophyta): an addition to the N.W. Atlantic species of Cladophora. Botanica Marina 31, p. 521-523, figs 1-3.

Acrocladus pygmaeus (Reinke) Boedeker comb. nov.

Basionym: Cladophora pygmaea Reinke 1888. Einige neue braune und grüne Algen der Kieler Bucht. Berichte der deutschen botanischen Gesellschaft 6, p. 241.

Acrocladus radiosus (Suhr) Boedeker comb. nov.

Basionym: Conferva radiosa Suhr 1834. Übersicht der Algen, welche von Hrn. Ecklon an der südafrikanischen Küste gefunden worden sind. Flora 17 (46, 47), p. 741.

Acrocladus rhodolithicolus (Leliaert) Boedeker comb. nov.

Basionym: Cladophora rhodolithicola Leliaert 2009. Cladophora rhodolithicola sp. nov. (Cladophorales, Chlorophyta), a diminutive species from European Maerl beds. European Journal of Phycology 44, p. 164, figs $1-20$.

Acrocladus sakaii (I.A. Abott) Boedeker comb. nov.

Basionym: Cladophora sakaii I.A. Abott 1972. Taxonomic and nomenclatural notes on North Pacific marine algae. Phycologia 11, p. 259-265.

Willeella clade: two species are placed in this wellsupported clade for which we re-erect the genus Willeella, namely C. ordinata and C. montagneana. The genus Willeella, based on the type species W. ordinata Børgesen, was originally placed in the Anadyomenaceae by Børgesen (1930). van den Hoek (1979) transferred W. ordinata to Cladophora, and placed it in the section Willeella (van den Hoek 1982). Other authors suggested to retain the name Willeella and wait for a new classification of the Cladophorales based on molecular data (Silva et al. 1996). In addition to $W$. ordinata, two other species have been described for Willeella: W. japonica Yamada \& Segawa and W. mexicana Dawson. Willeella mexicana is regarded as a synonym of Phyllodictyon robustum (Setchell \& Gardner) Leliaert \& Wynne (Leliaert et al. 2008), and van den Hoek and Chihara (2000) reduced W. japonica to a synonym of C. ordinata. However, there is striking difference in habitat: while the species occurs frequently in the intertidal and shallow subtidal in South Africa (but also down to $37 \mathrm{~m}$, Leliaert and Coppejans 2003), the Japanese populations have only been encountered between 25 and $45 \mathrm{~m}$ depth (van den Hoek and Chihara 2000), thus molecular data might reveal the existence of more than one lineage in C. ordinata.

Cladophora montagneana can occur as a range of growth forms and can be short and rigid (e.g., Gordon et al. 1985) or rather flaccid with long unbranched proliferations, especially in culture (van den Hoek 1984, van den Hoek and Chihara 2000). Densely branched forms of C. montagneana resemble an irregular version of $C$. ordinata, with short, tapering branchlets, conical apical cells and up to six laterals per cell (see van den Hoek 1984, van den Hoek and Womersley 1984, Gordon et al. 1985, van den Hoek and Chihara 2000). Both species grow mainly by intercalary cell divisions. It has been reported that the two species have been confused with each other (Leliaert and Coppejans 2003). However, the morphologically very variable C. montagneana most commonly does not bear any resemblance to $C$. ordinata, as the thalli are typically lined with short branches unilaterally and contain long unbranched parts especially in the apical regions.

Species such as C. brasiliana G. Martens, C. chlorocontracta C. Hoek, C. jongiorum C. Hoek that have been speculated to be close relatives of C. montagneana (see van den Hoek 1982) or species such as C. willeelloides Kraft that have been speculated to be close relatives of $C$. ordinata (Kraft 2000), will not be transferred to Willeella until molecular data is available for those taxa.

Willeella Børgesen emend. Boedeker

Dark to medium green, branched, uniseriate, filamentous marine algae, attached by branching basal holdfasts or unattached as aegagropiloid tufts. Diameter of apical cells 24-45 $\mu \mathrm{m}$, of main axes 56$175 \mu \mathrm{m}$. Typical, albeit not diagnostic, morphological characters are: main axis or primary laterals lined with short, tapering branchlets, mainly intercalary cell divisions, conical apical cells and up to six laterals per cell. Distinct lineage in phylogenetic reconstructions based on rDNA sequences (GenBank LT607097, LT607098, LT607099).

Type species: Willeella ordinata Børgesen 1930. Some Indian green and brown algae especially from the shores of the Presidency of Bombay. Journal of the Indian Botanical Society 9, p. 155, figs 3, 4a,b, pl. I: fig. 1.

Holotype: Port Okha, Gujarat, India (Silva et al. 1996), in C.

Synonyms: Wittrockiella japonica Yamada \& Segawa 
Willeella montagneana (Kützing) Boedeker comb. nov.

Basionym: C. montagneana Kützing 1849. Species algarum. F. A. Brockhaus, Leipzig, p. 415.

Rhizoclonum africanum clade: the tropical $R$. africanum clade contains at least four lineages with a Rhizoclonium-like morphology (Fig. 8, A-C), for which we create the new genus Pseudorhizoclonium (see below). To decide which of these four lineages is the type species $R$. africanum will require more sampling and more detailed phylogenetic and morphometric investigations. For the time being we just create the new genus for this clade and are not making taxonomic changes at the species level.

$R$. africanum (including the synonyms $R$. hookeri Kützing, and $R$. samoense Setchell) is distributed in the tropics worldwide, while $R$. rhizophilum has only been recorded from Galapagos, Costa Rica and Panama (see Guiry and Guiry 2015). Another species that is likely a member of this clade is $R$. crassipellitum West \& West, a large-celled species described from tropical Africa. The filaments of this clade can have larger cell dimensions (up to $100 \mu \mathrm{m})$ than the true Rhizclonium clade, and appear to be characterized by very thick cell walls in field material $(>10 \mu \mathrm{m}$, Fig. $8 \mathrm{D})$ but this character can be lost in culture (see Fig. 1, B and C). The presence or absence of rhizoids is also variable, and filaments that had rhizoids when collected did not produce any rhizoids when grown in culture (see Fig. 1, B and C), illustrating considerable phenotypic plasticity in response to environmental conditions. While species of the $R$. riparium clade have few nuclei per cell, typically less than eight (Hamel 1930, Geitler 1936, Sinha 1958, Parodi and Cáceres 1993), species in the $R$. africanum clade typically contain 30-40 nuclei per cell (Tsutsui et al. 2012). Another feature only known from members of this clade and not found in the $R$. riparium clade is the presence of "knees" in which the filaments display sharp-angled bends (see also Taylor 1945). This feature was present in the samples of $R$. rhizophilum and in samples of $R$. africanum from Kosrae, Micronesia (sample G98) and from Thailand (Fig. 8, E and F). The sample from Madagascar, the sister lineage to the other three lineages in the clade (see Fig. 4) contained filaments that ended in chains of zoidangia with an exit pore in the middle of the cells.

\section{Pseudorhizoclonium Boedeker gen. nov.}

Description: Filaments are $30-100 \mu \mathrm{m}$ in diameter. The filaments can have no, few or many short lateral rhizoids (Fig. 8, B and C), and consist of short cells that typically have a thick cell wall $(>10 \mu \mathrm{m}$, Fig. 8D). Filaments can occur unattached, attached by secondary rhizoids, or attached by a basal cell (Fig. 8B). Knees may be present in which the filaments display sharp-angled bends, often with a short continuation of the cell below the bend (Fig. 8, E and F). Cells contain more than 20, typically 30-40 nuclei per cell. Restricted to the tropics and typically found in mangroves, lagoons or the high intertidal zone, appears to be well-adapted to brackish waters and changing salinities. Distinct from Rhizoclonium in rDNA sequences (GenBank LT607119, LT607121, LT607125, LT607127, LT607130, LT607131).

Etymology: Named for its morphological similarity to the genus Rhizoclonium.

Type species: Pseudorhizoclonium africanum (Kützing) Boedeker comb. nov.

Basionym: R. africanum Kützing 1853. Tabulae phycologicae; oder, Abbildungen der Tange. Vol. III. W. Köhne, Nordhausen, p. 21, pl. 67: fig. II.

Holotype: Senegambia, Africa, in L(?).

Synonyms: Rhizoclonium hookeri Kützing, Rhizoclonium samoense Setchell

Pseudorhizoclonium rhizophilum (W.R. Taylor) Boedeker comb. nov.

Basionym: Rhizoclonium rhizophilum W.R. Taylor 1945. Pacific marine algae of the Allan Hancock Expeditions to the Galapagos Islands. Allan Hancock Pacific Expeditions 12, p. 55.

Slippery green filaments: this group includes unbranched specimens (Fig. 9, A-C) from South Africa, Mauritius and the Cayman Islands and is clearly distinct from the other Chaetomorpha-like lineages in phylogenetic reconstructions. It is also distinct from the $R$. africanum clade $(\sim 5 \%-6 \%$ different in LSU sequences), and we describe a new genus for this clade: Lubrica gen. nov. As the four specimens known to belong to this clade have identical LSU sequences we assume for the time being that there is a single species, Lubrica zinkwasii Boedeker sp. nov. (see below). However, it is obvious that this lineage is undersampled and generally insufficiently known. While morphologically indistinguishable from Chaetomorpha, the smoothness and slipperiness are unique for this new genus. To place a specimen into this lineage with confidence, the sample would need to be sequenced. The type species of the genus Lola A. Hamel \& G. Hamel, Lola lubrica (Setchell \& N.L. Gardner) A. Hamel \& G. Hamel had also been described as slippery, but differs in cell dimensions (diameter $30-50 \mu \mathrm{m}$ ) and had been described from the cold-temperate Pacific coast of California (Gardner 1919, Hamel and Hamel 1929) and is regarded as a synonym of Chaetomorpha ligustica (Kützing) Kützing (Silva et al. 1987, 1996), which is a member of the distantly related Chaetomorpha clade (see Fig. 5), therefore we regard it as justified to create a new genus.

Lubrica zinkwasii Boedeker gen. et sp. nov.

Description: Very smooth, slippery, bright green filaments; filament diameter variable (Fig. 9A), 40$220 \mu \mathrm{m}$; growth by intercalary cell divisions (Fig. 9B); cells cylindrical or slightly constricted where cells join (Fig. 9A), 1.5-3.5 times as long as broad (Fig. 9C). Each cell contains dozens of nuclei 


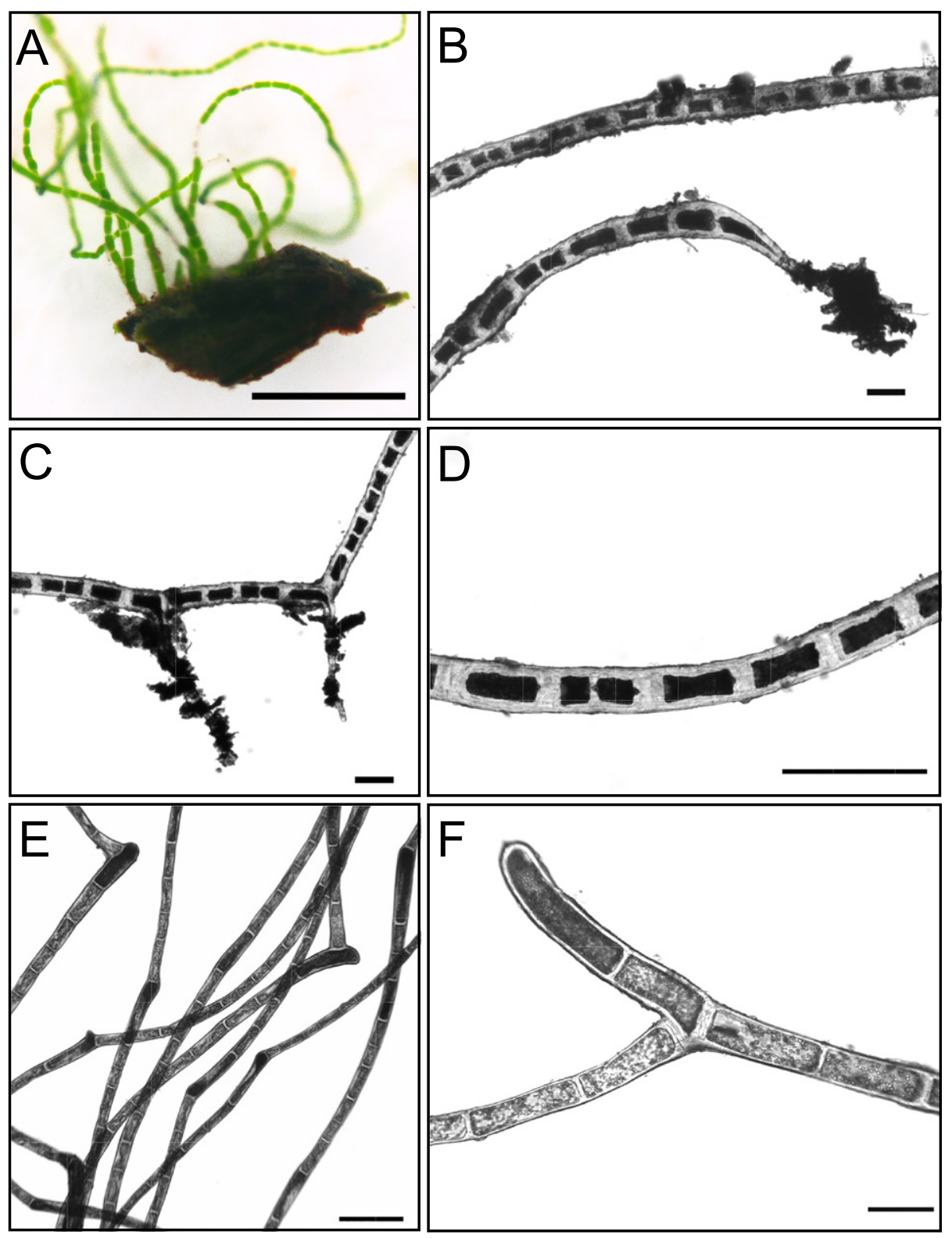

FIG. 8. Morphological features of Pseudorhizoclonium gen. nov. (A) Unbranched filaments growing on a piece of mangrove bark (Laguncularia sp.) from Las Bombas, Brazil; scale bar $=1 \mathrm{~mm}$. (B) Unbranched filament and basal cell with holdfast of Pseudorhizoclonium africanum from mangroves from Bais, Philippines (specimen GENT: FL1165), scale bar $=500 \mu \mathrm{m}$. (C) Filament of P. africanum with lateral rhizoids (specimen GENT: FL1165), scale bar $=500 \mu \mathrm{m}$. (D) Filament of $P$. africanum showing thick layered cell walls (specimen GENT: FL1165), scale bar $=100 \mu \mathrm{m}$. (E) Filaments of $P$. africanum from Thailand (specimen GENT: HEC16747) with "knees," in which the filaments display sharp-angled bends, scale bar $=100 \mu \mathrm{m}$. (F) Detail of a "knee" with the knee cell expanding further and producing another cell, resulting in a short secondary branch (specimen GENT: HEC16747), scale bar $=100 \mu \mathrm{m}$.

(Fig. 9D), and numerous round or polygonal chloroplasts with relatively large pyrenoids (ca. $5 \mu \mathrm{m}$ in diameter, Fig. 9E). Only known unattached, from estuaries and mangroves in the tropics. Distinct in LSU rDNA sequences (GenBank LT607135).

Etymology: Named after the slippery nature of the filaments. The species epithet refers to the location, Zinkwasi lagoon in KwaZulu-Natal, South Africa, where this species was first recognized as something unique.
Holotype: loose-lying on mud, Palm Beach estuary, Eastern Cape, South Africa, 22.XIII.2005, Boedeker, WELT: A033222.

Sequence data: GenBank LT607135.

\section{CONCLUSIONS}

This study inferred the phylogenetic relationships in the Cladophoraceae based on LSU and SSU rDNA sequences, selected from a dataset of 362 sequenced specimens. The Cladophoraceae is 

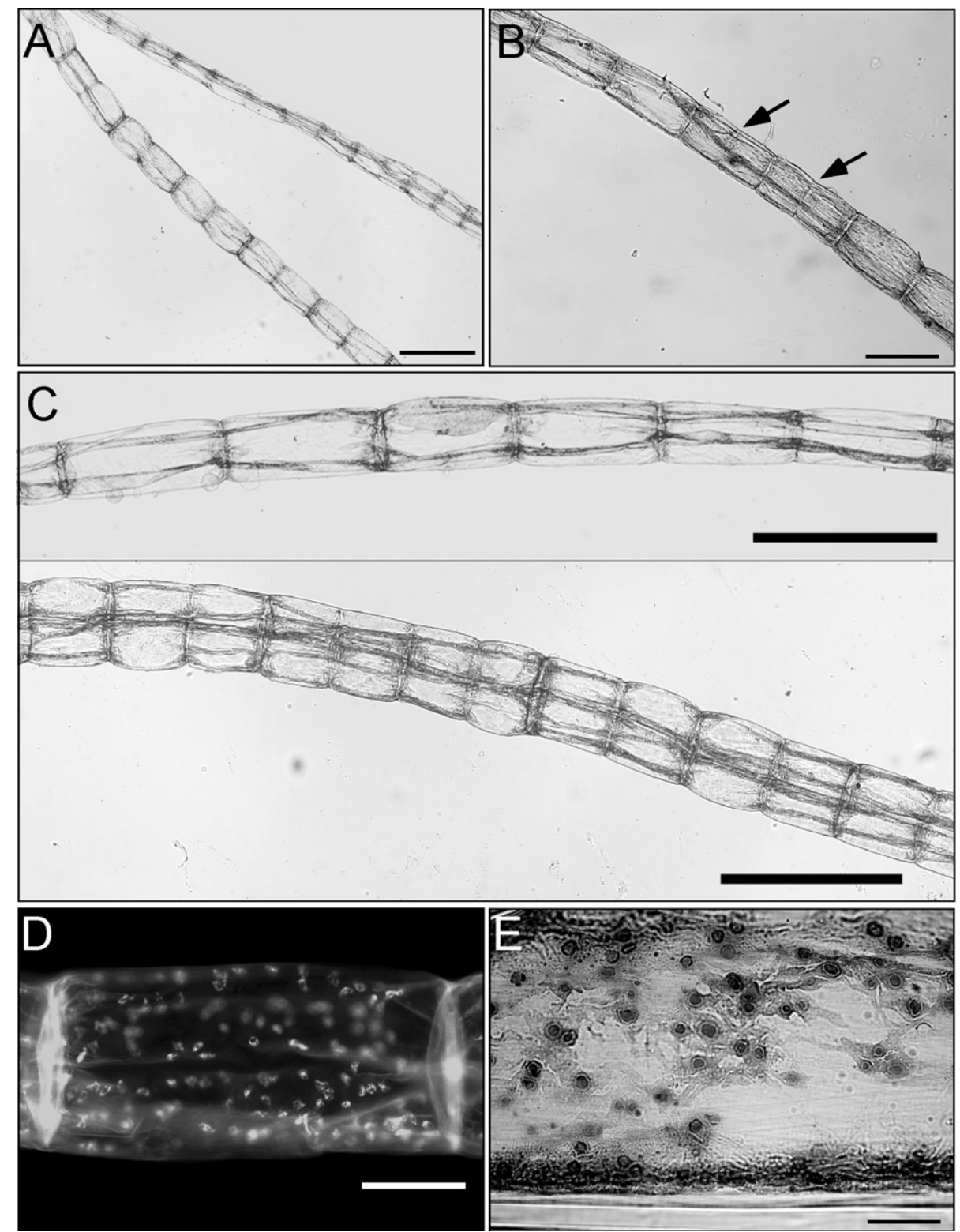

Fig. 9. Morphological features of Lubrica zinkwasii gen et sp. nov., as displayed in rehydrated herbarium material. (A) Variation in filament width and cell shape (type specimen, voucher WELT: A033222), scale bar $=500 \mu \mathrm{m}$. (B) Filament showing intercalary cell divisions (arrows) (voucher WELT: A033219), scale bar $=200 \mu \mathrm{m} .(\mathrm{C})$ Comparison of short- and long-celled filaments and illustration of very thin cell walls (type specimen, voucher WELT: A033222), scale bars $=500 \mu \mathrm{m}$. (D) Numerous nuclei within cells, stained with DAPI, scale bar $=100 \mu \mathrm{m}$. (E) Numerous pyrenoids within cells, stained with Lugol's iodine, scale bar $=20 \mu \mathrm{m}$.

now a well-defined clade and family that encompasses the genera Cladophora s.s., Chaetomorpha, Rhizoclonium, Willeella, Acrocladus, Lubrica, and Pseudorhizoclonium (see Fig. 2). The backbone of the phylogeny is robust and the relationships of the main lineages within the group are clarified. This is a first step toward a taxonomy that represents the evolutionary history of the group. Adjustments still need to be made with regards to the generic placement of C. rupestris and Ch. melagonium, as well as at the species level within the genera. This study also showcases the need for both increased sampling and sequencing efforts and new discoveries in this group most certainly can still be made, as illustrated by the finding of the new lineage Lubrica. Seriously undersampled regions include Africa, the Southern Ocean and the freshwater realm. We hope that the less confused taxonomy and nomenclature will invite further studies investigating the evolution of this species rich and widespread group of morphologically simple but fascinating algae.

We would like to thank Bertie J. van Heuven and Marcel Eurlings (Naturalis, Leiden, Netherlands) for valuable laboratory assistance. For images, we acknowledge Ken Ryan 
(Victoria University Of Wellington, New Zealand) for Figure 1E (Chaetomorpha coliformis) and Robert Anderson (Seaweed Unit, Marine \& Coastal Management, University of Cape Town, South Africa) for Figure 1D (W. ordinata). This study would not have been possible without the help of many colleagues providing samples, and we would like to express our gratitude to Rob Anderson, Kai Bischof, Andrea Bernecker, Juliet Brodie, Francis Bunker, Maria Ciancia, Eric Coppejans, Olivier De Clerck, Stefano G. A. Draisma, Angelika Dummermuth, Árni Einarsson, Tracy Farr, Karl Gunnarsson, Gayle I. Hansen, Svenja Heesch, Jonathan Henwood, Lilo Herre, Sven Ihnken, Hans Kruijer, Diane Littler, Mark Littler, Christine A. Maggs, Lynne McIvor, Sheryl Miller, Wendy A. Nelson, Kate Neill, Ruth Nielsen, Antoine N'Yeurt, Birgit Petersen, Thomas Pröschold, Willem Prud'homme van Reine, Maria Eliana Ramirez, Eva Rothäusler, Jan Rueness, Tom Schils, Christof Schygulla, Lennert Tyberghein, Herre Stegenga, Loes Venekamp, Heroen Verbruggen, Andreas Wagner, John A. West, Christian Wiencke, and Bryan Wysor. Jenny Bryant and Jo Wilbraham (Natural History Museum, London), Gerard Thijsse and Nicolien Sol (Naturalis Biodiversity Center, Leiden, Netherlands) as well as Jenn Dalen and Antony Kusabs (Te Papa Tongarewa National Museum of New Zealand, Wellington) are thanked for assistance with voucher specimens. We thank Olivier De Clerck for nomenclatural advice, CB acknowledges the German Academic Exchange Service (DAAD) and the Royal Society of New Zealand (Marsden Fund) for postdoctoral scholarships. All authors declare that there is no conflict of interest.

Abbott, I. A. \& Hollenberg, G. J. 1976. Marine Algae of California. Stanford University Press, Stanford, California, 827 pp.

Alves, A. M., Gestinari, L. M. S., Oliveira, I. S., Moniz-Brito, K. L. \& Moura, C. W. N. 2012. The genus Cladophora (Chlorophyta) in the littoral of Bahia, Brazil. Nova Hedwigia 95:33772.

Bakker, F. T., Olsen, J. L. \& Stam, W. T. 1995. Global phylogeography in the cosmopolitan species Cladophora vagabunda (Chlorophyta) based on nuclear rDNA internal transcribed spacer sequences. Eur. J. Phycol. 30:197-208.

Bakker, F. T., Olsen, J. L., Stam, W. T. \& van den Hoek, C. 1994. The Cladophora complex (Chlorophyta): new views based on 18S rRNA gene sequences. Mol. Phylogen. Evol. 3:365-82.

Blair, S. M. 1983. Taxonomic treatment of the Chaetomorpha and Rhizoclonium species (Cladophorales; Chlorophyta) in New England. Rhodora 85:175-211.

Blair, S. M., Mathieson, A. C. \& Cheney, D. P. 1982. Morphological and electrophoretic investigations of selected species of Chaetomorpha (Chlorophyta, Cladophorales). Phycologia 21:164-72.

Boedeker, C., O’Kelly, C. J., Star, W. \& Leliaert, F. 2012. Molecular phylogeny and taxonomy of the Aegagropila clade (Cladophorales, Chlorophyta), including the description of Aegagropilopsis gen. nov. and Pseudocladophora gen. nov. J. Phycol. 48:808-25.

Bold, H. C. \& Wynne, M. J. 1985. Introduction to the Algae, 2nd edn. Prentice-Hall, Englewood Cliffs, New Jersey, 720 pp.

Boraso de Zaixso, A. 2004. Chlorophyta marinas de la Argentina. Historia Natural, Buenos Aires (Segunda Serie) 3:95-119.

Børgesen, F. 1913. The marine algae of the Danish West Indies. Part 1. Chlorophyceae. Dansk Botanisk Arkiv 1:1-158.

Børgesen, F. 1930. Some Indian green and brown algae especially from the shores of the Presidency of Bombay. J. Ind. Bot. Soc. 9:151-74

Børgesen, F. 1948. Some marine algae from Mauritius. Additional lists to the Chlorophyceae and Phaeophyceae. Kongelige Danske Videnskabernes Selskab, Biologiske Meddelelser 20:1-55.

Brand, F. 1909. Zur Morphologie und Biologie des Grenzgebietes zwischen den Algengattungen Rhizoclonium und Cladophora. Hedwigia 48:45-73.
Chapman, V. J. \& Chapman, D. J. 1973. The Algae. Macmillan Press Ltd., London, UK, 497 pp.

Christensen, T. 1957. Chaetomorpha linum in the attached state. Botanisk Tidsskrift 53:311-6.

Cocquyt, E., Verbruggen, H., Leliaert, F. \& De Clerck, O. 2010. Evolution and cytological diversification of the green seaweeds (Ulvophyceae). Mol. Biol. Evol. 27:2052-61.

Coppejans, E. 1995. Flore algologique des côtes du Nord de la France et de la Belgique. Scripta Botan. Belg. 9:1-454.

Cormaci, M., Furnari, G. \& Alongi, G. 2014. Flora marina bentonica del Mediterraneo: Chlorophyta. Boll. Accad. Gioenia Sci. Nat. 47:11-436.

De Clerck, O., Guiry, M. D., Leliaert, F., Samyn, Y. \& Verbruggen, H. 2013. Algal taxonomy: a road to nowhere? J. Phycol. 49:215-25

Deng, Y., Tang, X., Zhan, Z., Teng, L., Ding, L. \& Huang, B. 2013. Culture observation and molecular phylogenetic analysis on the blooming green alga Chaetomorpha valida (Cladophorales, Chlorophyta) from China. Chinese J. Oceanol. Limnol. 31:552-9.

Dodds, W. K. 1991. Factors associated with dominance of the filamentous green alga Cladophora glomerata. Water Res. 25:132532.

Edgar, R. C. 2004. MUSCLE: multiple sequence alignment with high accuracy and high throughput. Nucl. Acids Res. 32:17927 .

Egerod, L. E. 1952. An analysis of the siphonous Chlorophycophyta with special reference to the Siphonocladales, Siphonales, and Dasycladales of Hawaii. Univ. Calif. Publ. Bot. 25:327-67.

Famà, P., Jousson, O., Zaninetti, L., Meinesz, A., Dini, F., Di Giuseppe, G., Millar, A. J. K. \& Pawlowski, J. 2002. Genetic polymorphism in Caulerpa taxifolia (Ulvophyceae) chloroplast DNA revealed by a PCR-based assay of the invasive Mediterranean strain. J. Evol. Biol. 15:618-24.

Famà, P., Olsen, J. L., Stam, W. T. \& Procaccini, G. 2000. High levels of intra- and inter-individual polymorphism in the rDNA ITS1 of Caulerpa racemosa (Chlorophyta). Eur. J. Phycol. 35:349-56.

Feldmann, J. 1938. Sur la classification de l'ordre des Siphonocladales. Rev. Gen. Bot. 50:571-97.

Felsenstein, J. 1985. Confidence limits on phylogenies: an approach using the bootstrap. Evolution 39:783-91.

Flindt, M., Salomonsen, J., Carrer, M., Bocci, M. \& KampNielsen, L. 1997. Loss, growth and transport dynamics of Chaetomorpha aerea and Ulva rigida in the Lagoon of Venice during an early summer field campaign. Ecol. Mod. 102:13341.

Fučíková, K., Leliaert, F., Cooper, E. D., Škaloud, P., D’hondt, S., De Clerck, O., Gurgel, C. F. D. et al. 2014. New phylogenetic hypotheses for the core Chlorophyta based on chloroplast sequence data. Front. Ecol. Evol. 2:63.

Furumoto, J. R. 2009. A Multigene Phylogenetic Reconstruction of the Green Algal Class Ulvophyceae (Chlorophyta). Master thesis, California State University Fresno, College of Science and Mathematics, California, USA.

Gardner, N. L. 1919. New Pacific coast marine algae IV. Univ. Calif. Publ. Bot. 6:487-96.

Geitler, L. 1936. Vergleichende Untersuchungen über den feineren Kern- und Chromosomenbau der Cladophoraceen. Planta 25:530-78.

Gestinari, L. M. S., Oliveira, M. C., Milstein, D., Yoneshigue-Valentin, Y. \& Pereira, S. M. B. 2009. Phylogenetic analyses of Cladophora vagabunda (L.) C. Hoek (Cladophorales, Chlorophyta) from Brazil based on SSU rDNA sequences. Revista Brazil. Bot. 32:531-8.

Goff, L. \& Moon, D. 1993. PCR amplification of nuclear and plastid genes from algal herbarium specimens and algal spores. J. Phycol. 29:381-4.

Gordon, D. M., van den Hoek, C. \& McComb, A. J. 1985. An aegagropiloid form of the green alga Cladophora montagneana Kütz. (Chlorophyta, Cladophorales) from southwestern Australia. Bot. Mar. 27:57-65. 
Gubelit, Y. I. \& Kovalchuk, N. A. 2010. Macroalgal blooms and species diversity in the transition zone of the eastern Gulf of Finland. Hydrobiologia 656:83-6.

Guiry, M. D. \& Guiry, G. M. 2015. AlgaeBase. World-wide electronic publication, National University of Ireland, Galway. Available at http://www.algaebase.org (accessed 26 August 2015).

Hamel, G. 1924. Quelques Cladophora des côtes françaises. Rev. Algol. 1:168-74.

Hamel, G. 1930. Chlorophycées des côtes françaises. Imprimerie Wolf, Rouen, France, 168 pp.

Hamel, A. \& Hamel, G. 1929. Sur l'hétérogamie d'une Cladophoracée Lola (nov. gen.) lubrica (Setch. et Gardn.). C. r. hebd. Seanc. Acad. Sci. Paris 189:1094-6.

Hansgirg, A. 1886. Prodromus der Algenflora von Böhmen. Erster Theil enthaltend die Rhodophyceen, Phaeophyceen und einen Theil der Chlorophyceen. Archiv für die naturwissenschaftliche Landesdurchforschung von Böhmen 5:1-96.

Hanyuda, T., Wakana, I., Arai, S., Miyaji, K., Watano, Y. \& Ueda, K. 2002. Phylogenetic relationships within Cladophorales (Ulvophyceae, Chlorophyta) inferred from 18S rRNA gene sequences, with special reference to Aegagropila linnaei. J. Phycol. 38:564-71.

Hassouna, N., Michot, B. \& Bachellerie, J. P. 1984. The complete nucleotide sequence of mouse 28S rRNA gene. Implications for the process of size increase of the large subunit rRNA in higher eukaryotes. Nucleic Acids Res. 12:3563-83.

Hayakawa, Y.I., Ogawa, T., Yoshikawa, S., Ohki, K. \& Kamiya, M. 2012. Genetic and ecophysiological diversity of Cladophora (Cladophorales, Ulvophyceae) in various salinity regimes. Phycol. Res. 60:86-97.

Hayden, H. S., Blomster, J., Maggs, C. A., Silva, P. C., Stanhope, M. J. \& Waaland, J. R. 2003. Linnaeus was right all along: Ulva and Enteromorpha are not distinct genera. Eur. J. Phycol. 38:277-94.

van den Hoek, C. 1963. Revision of the European species of Cladophora. Brill E.J, Leiden, Netherlands, 248 pp.

van den Hoek, C. 1979. The phytogeography of Cladophora (Chlorophyceae) in the northern Atlantic Ocean, in comparison to that of other benthic algal species. Helgol. Meeresunters. 32:374-93.

van den Hoek, C. 1982. A taxonomic revision of the American species of Cladophora (Chlorophyceae) in the North Atlantic Ocean and their geographic distribution. Verh. Kon. Ned. Akad. Wetensch. Afd. Natuurk. Tweede Sect. 78:1-236.

van den Hoek, C. 1984. The systematics of the Cladophorales. In Irvine, D. E. G. \& John, D. M. [Eds.] Systematics of the Green Algae. Academic Press, London; Orlando, Florida, pp. 157 78 .

van den Hoek, C. \& Chihara, M. 2000. A taxonomic revision of the marine species of Cladophora (Chlorophyta) along the coasts of Japan and the Russian Far-east. National Science Museum (Tokyo) Monographs 19:1-242.

van den Hoek, C., Mann, D. G. \& Jahns, H. M. 1995. Algae. An Introduction to Phycology. Cambridge University Press, Cambridge, UK, $623 \mathrm{pp}$.

van den Hoek, C. \& Rios, N. D. 1972. Willeella ordinata Boergesen, 1930 (Chlorophyceae, Cladophorales): first record for America. J. Phycol. 8:207-8.

van den Hoek, C. \& Womersley, H. B. S. 1984. Genus Cladophora. In Womersley, H. B. S. [Ed.] The Marine Benthic Flora of Southern Australia. Part I. Government Printer, Adelaide, South Australia, pp. 185-213.

Hughey, J., Gabrielson, P. W., Rohmer, L., Tortolani, J., Silva, M., Miller, K. A., Young, J. D., Martell, C. \& Ruediger, E. 2014. Minimally destructive sampling of type specimens of Pyropia (Bangiales, Rhodophyta) recovers complete plastid and mitochondrial genomes. Sci. Rep. 4:5113.

Ichihara, K., Shimada, S. \& Miyaji, K. 2013. Systematics of Rhizoclonium-like algae (Cladophorales, Chlorophyta) from Japanese waters, based on molecular phylogenetic and morphological analyses. Phycologia 52:398-410.
Imai, M., Katavama, N. \& Yamaguchi, Y. 1997. Effects of salinity on growth, photosynthesis and respiration in a freshwater alga Rhizoclonium riparium (Chlorophyceae, Cladophorales). Phycol. Res. 45:233-7.

Jobb, G. 2011. TreeFinder. Available at http://www.treefinder.de (accessed 14 September 2015).

John, D. M., Whitton, B. A. \& Brook, A. J. 2002. The Freshwater Algal Flora of the British Isles. An Identification Guide to Freshwater and Terrestrial Algae. Cambridge University Press, Cambridge, $702 \mathrm{pp}$.

Jónsson, S. 1965. La validité et la délimitation de l'ordre des Siphonocladales. In: Travaux dédiés a Lucien Plantefol. Masson et Cie, Paris, pp. 391-406.

Jörger, K. M. \& Schrödl, M. 2013. How to describe a cryptic species? Practical challenges of molecular taxonomy. Front. Zool. 10:59.

Kornmann, P. 1972. Ein Beitrag zur Taxonomie der Gattung Chaetomorpha (Cladophorales, Chlorophyta). Helgol. Meeresunters. 23:1-31.

Koster, J. T. H. 1955. The genus Rhizoclonium Kützing in the Netherlands. Pubbl. Staz. Zool. Napoli 27:335-57.

Kraft, G. T. 2000. Marine and estuarine benthic green algae (Chlorophyta) of Lord Howe Island, south-western Pacific. Aus. Syst. Bot. 13:509-648.

Kützing, F. T. 1843. Über die Systematische Eintheilung der Algen. Linnaea 17:75-107.

Kützing, F. T. 1849. Species Algarum. F.A. Brockhaus, Leipzig, 922 pp.

Kützing, F. T. 1853. Tabulae Phycologicae, Vol III. W. Köhne, Nordhausen, $28 \mathrm{pp}, 100 \mathrm{pls}$.

Leliaert, F. \& Boedeker, C. 2007. Cladophorales. In Brodie, J., Maggs, C. A. \& John, D. [Eds.] Green Seaweeds of Britain and Ireland. Natural History Museum Publications, London, UK, pp. 131-83.

Leliaert, F., Boedeker, C., Peña, V., Bunker, F., Verbruggen, H. \& De Clerck, O. 2009b. Cladophora rhodolithicola sp. nov. (Cladophorales, Chlorophyta), a diminuitive species from European Maerl beds. Eur. J. Phycol. 44:155-69.

Leliaert, F. \& Coppejans, E. 2003. The marine species of Cladophora (Chlorophyta) from the South African east coast. Nova Hedwigia 76:45-82.

Leliaert, F. \& Coppejans, E. 2006. A revision of Cladophoropsis Børgesen (Siphonocladales, Chlorophyta). Phycologia 45:657-9

Leliaert, F., De Clerck, O., Verbruggen, H., Boedeker, C. \& Coppejans, E. 2007. Molecular phylogeny of the Siphonocladales (Chlorophyta: Cladophorophyceae). Mol. Phylogenet. Evol. 44:1237-56.

Leliaert, F., D'hondt, S., Tyberghein, L., Verbruggen, H. \& De Clerck, O. 2011b. Atypical development of Chaetomorpha antennina in culture (Cladophorales, Chlorophyta). Phycol. Res. 59:91-7.

Leliaert, F. \& Lopez-Bautista, J. M. 2015. The chloroplast genomes of Bryopsis plumosa and Tydemania expeditionis (Bryopsidales, Chlorophyta): compact genomes and genes of bacterial origin. BMC Genomics 16:204.

Leliaert, F., Payo, D. A., Calumpong, H. P. \& De Clerck, O. 2011a. Chaetomorpha philippinensis (Cladophorales, Chlorophyta), a new marine microfilamentous green alga from tropical waters. Phycologia 50:384-91.

Leliaert, F., Rousseau, F., de Reviers, B. \& Coppejans, E. 2003. Phylogeny of the Cladophorophyceae (Chlorophyta) inferred from partial LSU rRNA gene sequences: is the recognition of a separate order Siphonocladales justified? Eur. J. Phycol. 38:233-46.

Leliaert, F., Rueness, J., Boedeker, C., Maggs, C. A., Cocquyt, E., Verbruggen, H. \& De Clerck, O. 2009a. Systematics of the marine microfilamentous green algae Uronema curvatum and Urospora microscopica (Chlorophyta). Eur. J. Phycol. 44:487-96.

Leliaert, F., Verbruggen, H., Vanormelingen, P., Steen, F., López-Bautista, J. M., Zuccarello, G. C. \& De Clerck, O. 2014. DNA-based species delimitation in algae. Eur. J. Phycol. 49:179-96. 
Leliaert, F., Verbruggen, H., Wysor, B. \& De Clerck, O. 2009c. DNA taxonomy in morphologically plastic taxa: algorithmic species delimitation in the Boodlea complex (Chlorophyta: Cladophorales). Mol. Phylogen. Evol. 53:122-33.

Leliaert, F., Wysor, B., Verbruggen, H., Vlaeminck, C. \& De Clerck, O. 2008. Phyllodictyon robustum (Setchell et Gardner) comb. nov. (Siphonocladales, Chlorophyta), a morphologically variable species from the tropical Pacific coast of America. Crypt. Algol. 29:217-33.

Logares, R., Shalchin-Tabrizi, K., Boltovskoy, A. \& Rengefors, K. 2007. Extensive dinoflagellate phylogenies indicate infrequent marine-freshwater transitions. Mol. Phylogen. Evol. 45:887-903.

López-Bautista, J. M. \& Chapman, R. L. 2003. Phylogenetic affinities of the Trentepohliales inferred from small-subunit rDNA. Int. J. Syst. Evol. Microbiol. 53:2099-106.

Matsuyama-Serisawa, K., Serisawa, Y. \& Tanaka, J. 2004. Growth, maturation and photosynthesis of the brackish water alga Rhizoclonium sp. (Cladophoraceae, Chlorophyta) in relation to salinity. Phycol. Res. 52:204-10.

Mattox, K. R. \& Stewart, K. D. 1984. The classification of the green algae, a concept based on comparative cytology. In Irvine, D. E. G. \& John, D. M. [Eds.] Systematics of the Green Algae. Academic Press, London; Orlando, Florida, pp. $29-72$.

Muangmai, N., West, J. A. \& Zuccarello, G. C. 2014. Evolution of four Southern Hemisphere Bostrychia (Rhodomelaceae, Rhodophyta) species: phylogeny, species delimitation and divergence times. Phycologia 53:593-601.

Nelson, W. A., Farr, T. J. \& Broom, J. E. S. 2005. Dione and Minerva, two new genera from New Zealand circumscribed for basal taxa in the Bangiales (Rhodophyta). Phycologia 44:13945 .

Nienhuis, P. H. 1975. Biosystematics and ecology of Rhizoclonium riparium (Roth) Harvey (Chlorophyceae: Cladophorales) in the estuarine area of the rivers Rhine, Meuse and Scheldt. PhD thesis, University of Groningen, The Netherlands, 240 pp.

N'Yeurt, A. D. R. \& Payri, C. E. 2007. Marine algal flora of French Polynesia II. Chlorophyceae (green algae). Crypt. Algol. 28:388.

Nylander, J. A. A. 2004. MrModeltest2 v2.3. Available at http:// www.abc.se/ nylander/ (accessed 29 August 2015).

O'Kelly, C. J. \& Floyd, G. L. 1984. Correlations among patterns of sporangial structure and development, life histories and ultrastructural features in the Ulvophyceae. In Irvine, D. E. G. \& John, D. M. [Eds.] Systematics of the Green Algae. Academic Press, London; Orlando, Florida, pp. 121-56.

Parodi, E. R. \& Cáceres, E. J. 1993. Variation in number of apical ramifications and vegetative cell length in freshwater populations of Cladophora (Ulvophyceae, Chlorophyta). J. Phycol. 27:628-33.

Payo, D. A., Leliaert, F., Verbruggen, H., D'hondt, S., Calumpong, H. P. \& De Clerck, O. 2013. Extensive cryptic species diversity and fine-scale endemism in the marine red alga Portieria in the Philippines. Proc. R. Soc. B Biol. Sci. 280:2012-60.

Peerapornpisal, Y., Amornledpison, D., Rujjanawate, C., Ruangrit, K. \& Kanjanapothi, D. 2006. Two endemic species of macroalgae in Nan River, Northern Thailand, as therapeutic agents. Science Asia 32 (Suppl. 1):71-6.

Pochon, X., Atalah, J., Wood, S. A., Hopkins, G. A., Watts, A. \& Boedeker, C. 2015. Cladophora ruchingeri (C. Agardh) Kützing, 1845 (Cladophorales, Chlorophyta): a new biofouling pest of green-lipped mussel Perna canaliculus (Gmelin, 1791) farms in New Zealand. Aquat. Invasions 10:123-33.

Posada, D. \& Crandall, K. A. 1998. Modeltest: testing the model of DNA substitution. Bioinformatics 14:817-8.

Price, W. M. 1967. Some aspects of the biology and taxonomy of the unbranched Cladophorales. PhD thesis, University of Liverpool, UK, 107pp.

Prosser, S. W., Dewaard, J. R., Miller, S. E. \& Hebert, P. D. 2016. DNA barcodes from century-old type specimens using nextgeneration sequencing. Mol. Ecol. Res. 16:487-97.
Rambaut, A. 2007. Se-Al (multiple sequence alignment program), v2.0a11. Available at http://tree.bio.ed.ac.uk/software/seal (accessed 29 August 2015).

Rambaut, A. 2008. FigTree v.1.1.2. Available at http:// tree.bio.ed.ac.uk/software/figtree/ (accessed 14 September 2015).

Rambaut, A. \& Drummond, A. J. 2007. Tracer v1.6. Available at http://tree.bio.ed.ac.uk/software/tracer (accessed 29 August 2015).

Ronquist, F. \& Huelsenbeck, J. P. 2003. MRBAYES 3: Bayesian phylogenetic inference under mixed models. Bioinformatics 19:1572-4.

Round, F. E. \& Sims, P. A. 1981. The distribution of diatom genera in marine and freshwater environments and some evolutionary considerations. In Ross, R. [Ed.] Proceedings of the 6th Diatom Symposium on Recent and Fossil Diatoms. Koeltz Scientific Books, Königstein, Germany, pp. 301-20.

Sakai, Y. 1964. The species of Cladophora from Japan and its vicinity. Scient Pap Inst Algol Res Hokkaido Univ 5:1-104.

Santelices, B. 1989. Algas marinas de Chile. Distribución, ecología, utilización y diversidad. Ediciones Universidad Catóica de Chile, Santiago, Chile, 399 pp.

Sartoni, G. 1992. Research on the marine algae of South-central Somalia. 3. The Siphonocladales-Cladophorales complex. Webbia 46:291-326.

Saunders, G. W. \& Kucera, H. 2010. An evaluation of $r b c$ L, tufA, UPA, LSU and ITS as DNA barcode markers for the marine green macroalgae. Cryptogam. Algol. 31:487-528.

Shimodaira, H. 2002. An approximately unbiased test of phylogenetic tree selection. Syst. Biol. 51:492-508.

Shimodaira, H. \& Hasegawa, M. 1999. Multiple comparisons of log- likelihoods with applications to phylogenetic inference. Mol. Biol. Evol. 16:1114-6.

Shimodaira, H. \& Hasegawa, M. 2001. CONSEL: for assessing the confidence of phylogenetic tree selection. Bioinformatics $17: 1246-7$.

Silva, P. C. 1950. Generic names of algae proposed for conservation. Hydrobiologia 2:252-80.

Silva, P. C., Meñez, E. G. \& Moe, R. L. 1987. Catalogue of the benthic marine algae of the Philippines. Smithson. Contrib. Mar. Sci. 27:1-179.

Silva, P. C., Basson, P. W. \& Moe, R. L. 1996. Catalogue of Indian Ocean Algae. Univ. Calif. Publ. Bot. 79:1-1259.

Sinha, J. P. 1958. Chromosome numbers and lifecycles in members of Cladophorales. Br. Phyc. Bull. 1:24-7.

Skabichevsky, A. P. 1976. The Cladophoraceae in the flora of Lake Baikal. Byulleten Moskovskogo Obshchestva Ispytatelei Prirody, Otdel Biologicheskii 81:139-43.

Söderström, J. 1963. Studies in Cladophora. Bot. Gothoburgensia 1:1147.

Stegenga, H., Bolton, J. J. \& Andersen, R. J. 1997. Seaweeds of the South African West Coast. Contr. Bolus Herb. 18:1-655

van der Strate, H. J., Boele-Bos, S. A., Olsen, J. L., van de Zande, L. \& Stam, W. 2002. Phylogeographic studies in the tropical seaweed Cladophoropsis membranacea (Chlorophyta, Ulvophyceae) reveal a cryptic species complex. J. Phycol. 38:572-82.

Sutherland, J. E., Lindstrom, S. C., Nelson, W. A., Brodie, J., Lynch, M. D., Hwang, M. S., Choi, H.-G. et al. 2011. A new look at an ancient order: generic revision of the Bangiales (Rhodophyta). J. Phycol. 47:1131-51.

Swofford, D. L. 2002. PAUP*. Phylogenetic Analysis Using Parsimony (*and Other Methods), Version 4. Sinauer Associates, Sunderland, Massachusetts.

Taylor, W. R. 1945. Pacific marine algae of the Allan Hancock Expeditions to the Galapagos Islands. Allan Hancock Pac. Exped. 12:1-528.

Tautz, D., Arctander, P., Minelli, A., Thomas, R. H. \& Vogler, A. P. 2003. A plea for DNA taxonomy. Trends Ecol. Evol. 18:70-4.

Thiers, B. 2016 [continuously updated]. Index Herbariorum: A global directory of public herbaria and associated staff. New York Botanical Garden's Virtual Herbarium. Available at http://sweetgum.nybg.org/science/ih/ (accessed 29 August 2016). 
Tsutsui, I., Kaoru, H., Dusit, A.-U., Jaruwan, S., Prapansak, S., Suneerat, R., Sirimas, K., Monthon, G., Paveena, T. \& Yukio, M. 2012. Common underwater plants in coastal areas of Thailand. Jircas International Agricultural Series 21:1-171.

Verbruggen, H. 2014. Morphological complexity, plasticity, and species diagnosability in the application of old species names in DNA-based taxonomies. J. Phycol. 50:26-31.

Verbruggen, H., Ashworth, M., LoDuca, S. T., Vlaeminck, C., Cocquyt, E., Sauvage, T., Zechman, F. W., Littler, D. S., Littler, M. M., Leliaert, F. \& De Clerck, O. 2009. A multi-locus timecalibrated phylogeny of the siphonous green algae. Mol. Phylogenet. Evol. 50:642-53.

Watanabe, S. \& Nakayama, T. 2007. Ultrastructure and phylogenetic relationships of the unicellular green algae Ignatius tetrasporus and Pseudocharacium americanum (Chlorophyta). Phycol. Res. 55:1-16.

Wehr, J. D. \& Sheath, R. G. 2003. Freshwater Algae of North America. Academic Press, San Diego, California, 917 pp.

West, J. A., Loiseaux de Goër, S. \& Zuccarello, G. C. 2014. A new species of Bangiopsis: B. franklynottii sp. nov. (Stylonematophyceae, Rhodophyta) from Australia and India and comments on the genus. Algae 29:101-9.

West, J. A., Scott, J. L., West, K. A., Clayden, S. L. \& Saunders, G. W. 2008. Rhodachlya madagascarensis gen. et sp. nov.: a distinct acrochaetioid represents a new order and family (Rhodachlyales ord. nov., Rhodachlyaceae fam. nov.) of the Florideophyceae (Rhodophyta). Phycologia 47:203-12.

Wille, N. 1890. Cladophoraceae. In Engler, A. \& Prantl, K. [Eds.] Die natürlichen Pflanzenfamilien I. Teil, Abt 2. Wilhelm Engelmann, Leipzig, Germany, pp. 114-9.

Womersley, H. B. S. 1984. The Marine Benthic Flora of Southern Australia, Part I. Government Printer, Adelaide, South Australia, 329 pp.

Yang, Z. 2007. PAML 4: a program package for phylogenetic analysis by maximum likelihood. Mol. Biol. Evol. 24:1586-91.

Zhang, X., Zhou, Y., Liu, P., Wang, F., Liu, B., Liu, X., Xu, Q. \& Yang, H. 2014. Temporal pattern in the bloom-forming macroalgae Chaetomorpha linum and Ulva pertusa in seagrass beds, Swan Lake lagoon, North China. Mar. Poll. Bull. 89:229-38.
Zhao, Z. J., Zhu, H., Hu, Z. Y. \& Liu, G. X. 2014. Occurrence of true branches in Rhizoclonium (Cladophorales, Ulvophyceae) and the reinstatement of Rhizoclonium pachydermum Kjellman. Phytotaxa 166:273-84.

Zhao, Z. J., Zhu, H., Liu, G. X. \& Hu, Z. Y. 2016. Rhizoclonium ramosum sp. nov. (Cladophorales, Chlorophyta), a new freshwater algal species from China. Fottea 16:12-21.

Zulkifly, S. B., Graham, J. M., Young, E. B., Mayer, R. J., Piotrowski, M. J., Smith, I. \& Graham, L. E. 2013. The genus Cladophora Kützing (Ulvophyceae) as a globally distributed ecological engineer. J. Phycol. 49:1-17.

\section{Supporting Information}

Additional Supporting Information may be found in the online version of this article at the publisher's web site:

Figure S1. Saturation plots.

Table S1. Genera of the Cladophoraceae that are currently not accepted.

Table S2. Information on specimens of taxa used in the phylogenetic analyses.

Table S3. List of specimens with identical LSU sequences.

Table S4. Characteristics of the species of the section Longi-articulatae Hamel. 